\title{
5. PALEOENVIRONMENTS IN THE WEDDELL SEA AREA AND ANTARCTIC CLIMATES, AS DEDUCED FROM CLAY MINERAL ASSOCIATIONS AND GEOCHEMICAL DATA, ODP LEG 113 ${ }^{1}$
}

\author{
Christian Robert ${ }^{2,3}$ and Henri Maillot ${ }^{4}$
}

\begin{abstract}
Clay particles in the Weddell Sea are mainly of detrital origin, eroded from soils as well as parent-rocks and ancient sediments. Contribution from volcanism is minor, and restricted to Early Cretaceous sediments on the Dronning Maud Land continental margin, and to Late Cretaceous through early Paleocene deposits on Maud Rise. Generally, weak diagenetic processes are reflected mainly by recrystallization of smectite particles. Clay mineral and inorganic geochemical data provide information about the evolution of continental climate and oceanic circulation in Antarctic areas adjacent to the Weddell Sea.

1. Globally warm climates and alternating wet and arid periods prevailed in Antarctica during the Cretaceous and early Paleogene. These conditions prevailed until the Eocene/Oligocene boundary in East Antarctica where an increased humidity is observed during the Paleocene. They lasted longer into the Oligocene in West Antarctica because it was warmed by southward flowing surface currents.

2. By early Oligocene, cold climatic conditions inhibited pedogenesis in East Antarctica. Similar conditions extended to West Antarctica during the middle Miocene, when widening and deepening of the Drake Passage and Scotia Sea completed the thermal isolation of Antarctica.

3. An important influence of Antarctic Water circulation on clay sedimentation is apparent since middle Miocene off East Antarctica and early Pliocene off West Antarctica. Increased deep water activity is evidenced during the early Pliocene (4.2-4.4 Ma to 3.0 Ma), late Pliocene (2.8-2.5 Ma to 2.0 Ma) and late Pleistocene (since 0.85 Ma).
\end{abstract}

\section{INTRODUCTION}

During Leg 113 of the Ocean Drilling Program in the Weddell Sea, nine sites were drilled on Maud Rise, Dronning Maud Land Continental Margin, in the Weddell Abyssal Plain, on the South Orkney Microcontinent, and in the Jane Basin (Fig. 1). These sites also form a depth transect across different water masses. Basic data about the sites is given in Table 1 . The purpose of this study is to reconstruct paleoenvironments from the investigation of clay mineralogy and inorganic geochemistry. Clay minerals are extremely sensitive to modifications of the environment: dramatic changes in continental morphology and climate have important repercussions on the genesis of the clays, and thus on the composition of oceanic detrital clay mineral associations, while minor variations of the environment influence only the relative abundances of the clay species (Millot, 1970; Chamley, 1989). As shown by previous studies from other oceanic areas, investigations of the fine terrigenous sediment fraction can provide a useful record of paleoclimate and paleoceanography: for example, clay associations can provide information about the origin of the clay particles and the climate of the source area (Biscaye, 1965; Chamley, 1979), the variations of continental humidity and the progress of desertification (Diester-Haass and Chamley, 1978; Stein and Robert, 1985; Robert and Chamley, 1987), and the influence of Antarctic Water circulation on clay sedimentation (Robert and Maillot, 1983). Clay mineral associations are used to understand the evolution of Antarctic climate, and of oceanic circulation in the Weddell Sea.

\footnotetext{
${ }^{1}$ Barker, P. F., Kennett, J. P., et al., 1990. Proc. ODP, Sci. Results, 113. College Station, TX (Ocean Drilling Program).

2 Institut de Géodynamique, CNRS-Université de Nice, France.

${ }^{3}$ Current address: Marine Science Institute/Department of Geological Sciences, University of California, Santa Barbara, CA 93106.

${ }^{4}$ Dynamique Sédimentaire et Structurale, Université de Lille 1, 59655 Villeneuve d'Ascq Cedex, France.
}

\section{METHODS}

\section{Clay Mineralogy}

Clay mineral investigations are based on a regular sampling of two samples per core, independent of the nature of the sediment. Each sample was sieved through a $63 \mu \mathrm{m}$ mesh and the fine fraction was leached in $0.2 \mathrm{~N}$ hydrochloric acid. The excess acid was removed by repeated centrifugations followed by homogenization. The $<2 \mu$ m size fraction was separated by decantation (settling time based on Stoke's law) and oriented aggregates were made on glass slides and dried at room temperature. Three X-ray analyses were run: (1) untreated sample; (2) glycolated sample; (3) sample heated for $2 \mathrm{hr}$ at $490^{\circ} \mathrm{C}$ (Holtzapffel, 1985). A Philips diffractometer equipped with a cobalt radiation source and a receiving slit of $1^{\circ}$ was used at scan speeds of $1^{\circ} 2 \theta / \mathrm{min}$, and with a time constant of $4 \mathrm{~s}$.

Semi-quantitative evaluations are based on the peak heights and areas. Clay minerals include chlorite, illite, irregular mixedlayers, vermiculite, smectite, kaolinite, and talc. The height of the 001 illite peak (glycolated sample) was taken as a reference. Compared to this value, clay minerals were corrected by multiplying their peak height by a factor of 0.5 to 2.5 , depending on their crystallinity. Data are given in percentages, the relative error being $5 \%$. The relative abundance of smectite vs. illite (S/I index) is obtained from the ratio of the 001 smectite $(18 \AA)$ and illite $(10 \AA)$ peaks of the glycolated sample. The illite crystallinity is the width (in $/ 10^{\circ} 2 \Theta$ ) of the 001 illite peak $(10 \AA)$ at midheight above the base line, measured on the diffractogram of the glycolated sample. The relative abundance of chlorite vs. illite $(\mathrm{C} / \mathrm{I}$ index) is obtained from the ratio of the 003 chlorite $(4.7 \AA)$ and 002 illite $(5.0 \AA)$ peaks of the natural sample. Associated minerals are non-clay minerals present in the clay fraction. Their abundance has been visually estimated, depending on the height of their diffraction peaks.

Some samples were selected for transmission electron microscopy analysis. The $<2 \mu \mathrm{m}$ size particles were scattered into a so- 


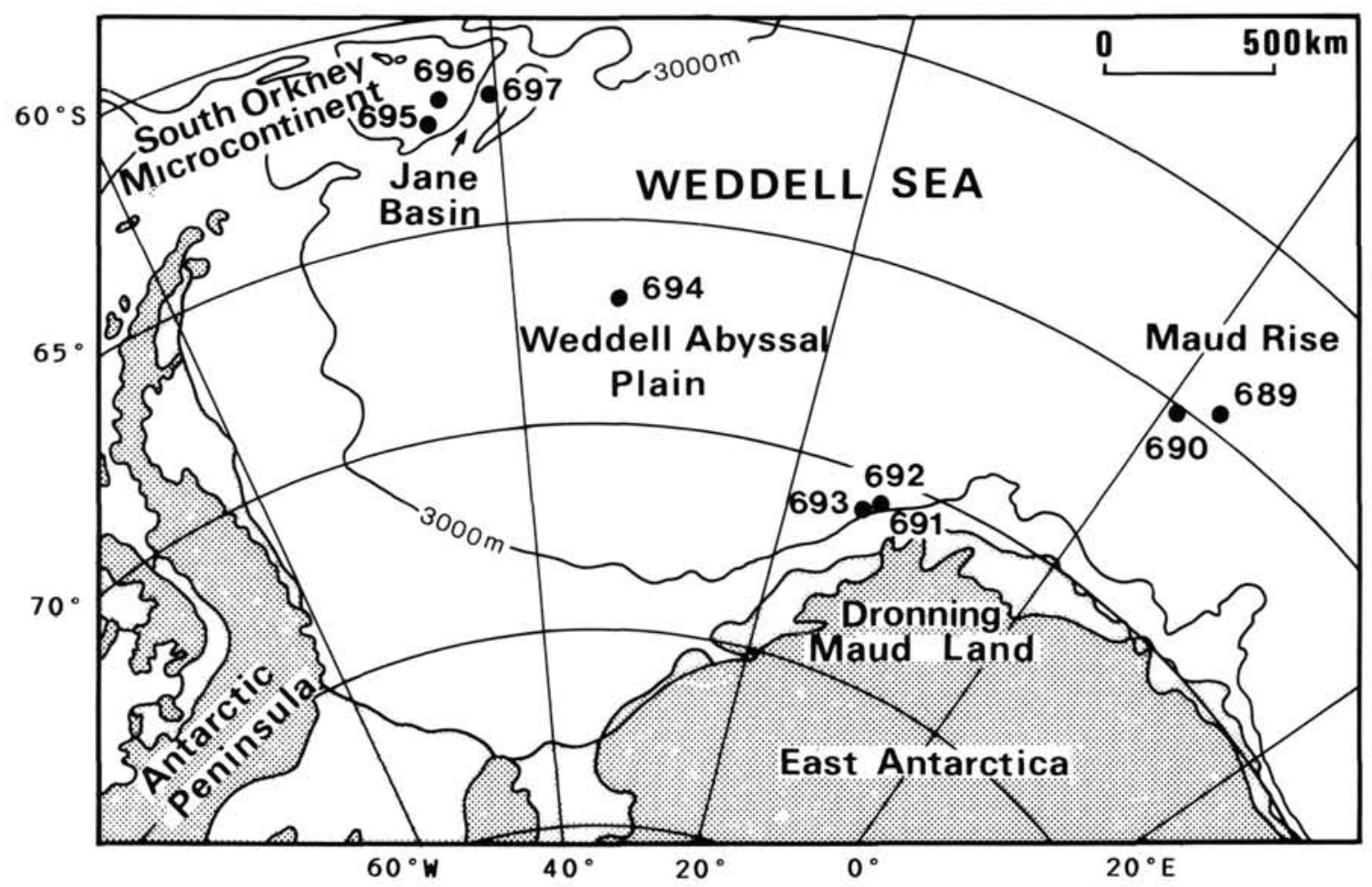

Figure 1. Location of Leg 113 Sites. $3000 \mathrm{~m}$ isobaths and ice-shelves shown.

Table 1. Main characteristics of Leg 113 sites.

\begin{tabular}{|c|c|c|c|c|c|}
\hline \multirow[b]{2}{*}{ Hole } & \multicolumn{2}{|c|}{ Position } & \multirow{2}{*}{$\begin{array}{l}\text { Water } \\
\text { depth } \\
\text { (m) }\end{array}$} & \multirow{2}{*}{$\begin{array}{l}\text { Penetration } \\
\text { (mbsf) }\end{array}$} & \multirow{2}{*}{$\begin{array}{l}\text { Oldest sediment } \\
\text { recovered }\end{array}$} \\
\hline & Latitude & Longitude & & & \\
\hline $689 A, B$ & $64^{\circ} 31.01^{\prime} \mathrm{S}$ & $03^{\circ} 05.99^{\prime} \mathrm{E}$ & 2080 & 297.3 & $\begin{array}{l}\text { middle Campanian- } \\
\text { lower Maestrichtian }\end{array}$ \\
\hline $690 \mathrm{~A}, \mathrm{~B}, \mathrm{C}$ & $65^{\circ} 09.63^{\prime} \mathrm{S}$ & $01^{\circ} 12.30^{\prime} \mathrm{E}$ & 2914 & 321.2 & $\begin{array}{l}\text { upper Campanian- } \\
\text { lower Maestrichtian }\end{array}$ \\
\hline $692 \mathrm{~A}, \mathrm{~B}$ & $70^{\circ} 43.43^{\prime} \mathrm{S}$ & $13^{\circ} 49.20^{\prime} \mathrm{W}$ & 2875 & 97.9 & Valanginian-Hauterivian \\
\hline $693 \mathrm{~A}, \mathrm{~B}$ & $70^{\circ} 49.89^{\prime} \mathrm{S}$ & $14^{\circ} 34.41^{\prime} \mathrm{W}$ & 2359 & 483.9 & upper Aptian-Albian \\
\hline $694 \mathrm{~A}, \mathrm{~B}, \mathrm{C}$ & $66^{\circ} 50.82^{\prime} \mathrm{S}$ & $32.26 .76^{\prime} \mathrm{W}$ & 4653 & 391.3 & middle Miocene \\
\hline $695 \mathrm{~A}$ & $62^{\circ} 23.48^{\prime} \mathrm{S}$ & $43^{\circ} 27.10^{\prime} \mathrm{W}$ & 1305 & 345.1 & upper Miocene \\
\hline 696A, B & $61^{\circ} 50.96^{\prime} \mathrm{S}$ & $42^{\circ} 56.00^{\prime} \mathrm{W}$ & 650 & 645.6 & middle Eocene \\
\hline $697 \mathrm{~A}, \mathrm{~B}$ & $61^{\circ} 48.63^{\prime} \mathrm{S}$ & $40^{\circ} 17.73^{\prime} \mathrm{W}$ & 3483 & 322.9 & lower Pliocene \\
\hline
\end{tabular}

lution of tert-butylamine. A drop of the suspension was then deposited on a copper grid, which had been previously covered by a membrane of collodion. The samples were analyzed using a Philips EM 300 electron microscope.

Interpretations are based on the geologic time-scale from Berggren et al., 1985, as modified in Barker, Kennett, et al., 1988.

\section{Inorganic Geochemistry}

Geochemical analyses were performed on one sample of bulk sediment every two cores. They include spectrophotometric analysis of $\mathrm{SiO}_{2}, \mathrm{MgO}, \mathrm{K}_{2} \mathrm{O}, \mathrm{Al}_{2} \mathrm{O}_{3}, \mathrm{Fe}_{2} \mathrm{O}_{3}$, and $\mathrm{Mn}$ by atomic absorption. In oceanic sediments, $\mathrm{Fe}$ and $\mathrm{Mn}$ originate from detrital or volcanic sources, and are concentrated by biogenic activity or diagenetic processes (Elderfield, 1977). Despite the variety of origins, relative abundances of $\mathrm{Fe}$ and $\mathrm{Mn}$ are suitable for paleoenvironmental studies (Turekian, 1965; Boström et al., 1976; Maillot, 1982). In marine sediments, $\mathrm{Fe}$ and $\mathrm{Mn}$ contents higher than those of typical detrital shales indicate an influence of the oceanic environment during sedimentation processes (Krishnaswani, 1976). The ratio log [Mn sample/Mn shale]/[Fe sample/
Fe shale] (Mn* index) was used, values of Mn shale and Fe shale being given by Boström et al., 1976. Variations of this index mainly relate to influences of volcanism and/or oxidizing currents (Maillot, 1982; 1986). $\mathrm{Al}$ is principally included in detrital particles. Comparison of $\mathrm{Al}$ with $\mathrm{Fe}$ and $\mathrm{Mn}$ contents using the ratio $\mathrm{Al} / \mathrm{Al}+\mathrm{Fe}+\mathrm{Mn}$ (D index) permits recognition of sediments dominated by a detrital fraction (Boström, 1970): D is close to 0.63 in typical terrigenous shales and decreases when terrigenous influence upon sedimentation is less significant. In most minerals, $\mathrm{Si}$ is associated with $\mathrm{Al}$, and the ratio $\mathrm{SiO}_{2}$ / $\mathrm{Al}_{2} \mathrm{O}_{3}$ ( $\mathrm{Si}^{*}$ index) expresses this relation. High values of this index are due to increases in Si from volcanogenic (ash), biogenic (diatoms, radiolarians) or detrital (quartz) sources rather than minerals also containing $\mathrm{Al}_{2} \mathrm{O}_{3}$.

\section{ORIGIN AND SIGNIFICANCE OF THE CLAY PARTICLES}

In Weddell Sea deposits, clay minerals originate through three main processes: continental weathering, alteration of volcanic products, and early diagenetic evolution. 


\section{Volcanic Influence}

On Maud Rise, the clay fraction of Late Cretaceous and $\mathrm{Pa}$ leogene sediments contains $65 \%$ to $100 \%$ smectite. On the Dronning Maud Land continental margin (Site 692), the clay fraction of a black-shale sequence of Valanginian to Hauterivian age contains $85 \%$ to $100 \%$ smectite, as well as lenses and laminae of volcanic ash (Barker, Kennett, et al., 1988). Electromicrographs indicate the presence of thick laths, and globular packs of laths (Pls. 1, 2). In the Philippine Sea, the clay fraction of altered basalts at DSDP Site 445 is largely dominated by well-crystallized smectite, which consists of large thick laths with a chemical composition closely related to those of tholeiitic basalts. Both abundances of smectite and of thick laths progressively decrease in the sediments above the basalt (Chamley, 1980). On the Walvis Ridge, the clay fraction of sediments overlying the basalt at DSDP Site 525 contains up to $100 \%$ well crystallized smectite, largely dominated by thick laths often associated in bundles. Their abundance decreases rapidly with distance above the basalt (Chamley et al., 1984). In the Tasman Sea, thick laths are present in small amounts in pelagic sediments from the southern Lord Howe Rise (DSDP Site 592), coeval with volcanic activity on the New Zealand margins during the late Eocene (Robert et al., 1985). Thick laths are considered as a characteristic feature of smectite particles formed during alteration of volcanic materials (Chamley and Bonnot-Courtois, 1981), and their presence in sedimentary sequences indicate a contribution from volcanic products.

In the Weddell Sea, volcanogenic particles are not exclusive and are associated with dominant fleecy particles (Pls. 1, 2) which generally form during pedogenesis (Beutelspacher and Van der Marel, 1968; Paquet, 1970). During the Late Cretaceous and until the Paleocene thick lathed particles were present on Maud Rise where volcanic glass and ash layers occurred during the Late Cretaceous (Barker, Kennett, et al., 1988). They are more abundant, and associated with high values of $\mathrm{Fe}$ and $\mathrm{Mg}$, at the shallower Site 689 , near the top of the rise. Medium values of the Mn* index suggest that volcanic activity was located in close proximity to the sites. Abundance of thick lathed particles decreases progressively during the early Paleocene, probably in relation to decreasing volcanic activity.

\section{Early Diagenesis}

On Dronning Maud Land continental margin, the clay fraction of Aptian-Albian sediments is dominated by smectite $(85 \%$ $95 \%$ ). Electromicrographs show the presence of widespread transparent thin laths. Ubiquity and apparent fragility of these laths suggest that they formed in situ (Pl. 2). Similar smectites have been described in Aptian-Albian and early Cenozoic sediments from the Atlantic (Holtzapffel and Chamley, 1986) where they originated during in situ recrystallization of smectite, within the interstitial sedimentary environment, and without any significant chemical or mineralogical change. Aptian-Albian lathed smectites from the Dronning Maud Land continental margin probably result from the same process. In the Weddell Sea, thin lathed smectites are also present throughout the Cenozoic series. However, they are generally less developed than in Cretaceous sediments, and are often associated with fleecy particles (Pls. 1, 2). Moreover, these laths are sometimes short, and display traces of dissolution (Pls. 2, 3). It is suggested that in Cenozoic sediments, thin lathed smectites partly result from erosion of ancient sediments, and have undergone transport by currents.

Thin and transparent laths are also present on the South Orkney Microcontinent at Site 696, in clay fractions containing up to $100 \%$ smectite (Plate 4 ). They are poorly developed in silty and clayey mudstones where detrital illite is also present (up to $25 \%$ ). Thin laths are dominant in coarse and porous sediments (sandy mudstone, muddy diatomaceous ooze) where they are especially long and flexuous.

In Section 113-696B-57R-1, a green level of silty mud contains $100 \%$ of poorly crystallized illite ("glauconite"). Significant $\mathrm{K}, \mathrm{Fe}$, and $\mathrm{Mg}$ contents, and very low values of both $\mathrm{D}$ and Mn* indices suggest that the sediment is mainly authigenic. Electromicrographs indicate the presence of rare large detrital particles, among widespread well-shaped laths and transparent crystals with sharp outlines (Plate 4). Similar illitic minerals have been described in thin layers of Purbeckian green marls from the Tethys (Deconinck et al., 1988). There, illite is present in shallow sedimentary sequences with some indications of evaporitic environments (including brackish, lacustrine, and hypersaline facies). The mineral results from transformation of detrital smectite in peritidal alkaline environments enriched in $\mathrm{K}$, submitted to periodic flooding and subsequent drying. The $\mathrm{K}$ can be supplied by leaching of alkaline volcanic products, ingression of seawater, or other processes. Shallow water environments with phases of possible local emergence were present on the South Orkney Microcontinent during the Paleogene (Barker, Kennett, et al., 1988). They could have locally favored the formation of authigenic illite in coastal areas.

\section{Detrital Supply and Main Significance of the Clay Minerals}

The D index generally shows high values at every site, indicating an important detrital supply, even at sites and during periods with indices of volcanic activity. Chlorite and illite are abundant in all Cenozoic sediments, especially from the Eocene/Oligocene boundary off East Antarctica, and from the middle Miocene upsection off the South Orkney microcontinent. Chlorite and illite are derived from erosion of the parentrock and of poorly developed soils; both are characterized by strong physical and weak chemical weathering, in which clay minerals cannot complete their evolution. Such conditions characterize areas of steep relief, where active mechanical erosion prevents the development of soils in accordance with continental climate and morphology (Millot, 1970; Chamley, 1979). These conditions are also fulfilled in cold and/or desert areas, where low temperatures as well as the absence of rainfall reduce the rate of chemical weathering (Millot, 1970). Small amounts of irregular mixed-layers occur at all sites, and in association with vermiculite at Sites 694 and 696. These minerals are formed preferentially under humid, temperate climates where cool temperatures and moisture allow a moderate hydrolysis. In twentythree modern soils of ice-free Antarctic regions (Ross area), widespread illite $(30 \%-90 \%)$ is locally associated with mixed-layers $(0 \%-20 \%)$, vermiculite $(0 \%-30 \%)$, chlorite $(0 \%-40 \%)$, and smectite $(0 \%-45 \%$, exceptionally $60 \%)$. Formation of smectite there is mainly driven by moisture, the mineral being abundant in wet, undrained hollows, and also present in soils on volcanic rocks (Campbell and Claridge, 1982).

Clay mineral composition and abundances of those soils formed in conditions of strong physical and weak chemical weathering are very similar to the clay mineral associations observed off East Antarctica since the early Oligocene (Figs. 2-4) and off West Antarctica since the middle Miocene (Figs. 5-8). In older sediments, clay mineral associations are largely dominated by smectite. In warm, tropical to sub-tropical areas, widespread smectite develops in low relief areas, as well as in confined environments of subsiding continental margins. Formation of smectite is also favored in soils on parent-rocks of basaltic origin. Soluble chemical elements (and detrital clay particles) are removed from upstream areas, and drained toward the ocean. However, they remain partly on the continent due to percolation or periodic water spreading in flat downstream areas where a poor drainage favors their accumulation. Subsequently, 
the soils are subjected to a rapid mineralogical evolution resulting in smectite formation. Evaporation during dry periods tends to concentrate the solutions and favors the genesis of smectite (Paquet, 1970; Gac, 1979).

Clay associations also contain a proportion of kaolinite. This mineral develops under warm and humid climatic conditions (Millot, 1970), and presently its abundance in oceanic sediments decreases toward high latitudes (Biscaye, 1965; Robert and Chamley, 1987). The first Cenozoic appearance of kaolinite on the Falkland Plateau has been recorded during the Paleocene, but the mineral is unknown at the same age in the Cape Basin and other South Atlantic regions (Robert, 1987). Therefore, kaolinite on Maud Rise (and at other Weddell Sea sites) probably originates from Antarctica: thus, appearance and variations of this mineral during the Paleocene, prior to the major deteriorations of climate, are probably directly related to climatic evolution of Antarctica.

Mainly derived from erosion of continental areas by winds as well as running water, the clay particles were then transported by both atmospheric and oceanic circulation to the depositional areas.

\section{EVOLUTION OF PALEOENVIRONMENTS IN THE WEDDELL SEA AREA}

Important differences in the temporal and geographical distribution of the clay minerals and chemical elements suggest that the Weddell Sea and surrounding Antarctic areas underwent a complex evolutionary history.

\section{Dronning Maud Land Continental Margin}

During the Early Jurassic, a distensive plate tectonics regime led to the initiation of a series of grabens which separated the Falkland Plateau and southernmost Africa to the North, from Antarctica to the South (Martin et al., 1982; Dingle et al., 1983). Late Jurassic sediments drilled at DSDP Site 330 on the Falkland Plateau display a transition from a clay mineral association containing abundant chlorite, illite, irregular mixed-layers, and kaolinite, toward a clay association characterized by dominant smectite (Robert and Maillot, 1983). This mineralogical change indicates a peneplanation on land, linked to the thermal subsidence of the continental margins of the Southern Ocean (Robert, 1987). Subsequently, smectite remained dominant to exclusive on the Falkland Plateau until the Paleogene.

On the conjugate margin of East Antarctica, Cretaceous terrigenous sediments have been penetrated. They are of Valanginian-Hauterivian age at Site 692, and of Aptian-Albian age at Site 693 (Barker, Kennett, et al., 1988). Clay mineral associations (Fig. 2) are largely dominated by smectite $(85 \%-100 \%)$. This indicates the presence of low-lying continental areas in Antarctica, where smectite developed in poorly drained environments: subsidence-induced peneplanation of the Antarctic margin of the Southern Ocean was already completed by the Valanginian, in agreement with the evolution previously evidenced on its northern margin, from DSDP sites drilled on the Falkland Plateau (Robert, 1987). Moreover, the presence of large amounts of smectite suggests the persistence of globally warm continental climates, with seasonally alternating wet and arid conditions. This appears consistent with the synthesis of Frakes, 1979, which indicates the extension of tropical to subtropical conditions as far as $70^{\circ} \mathrm{S}$, and warm to cool temperate climates beyond. However, poorly oxygenated waters covered the Dronning Maud Land continental margin until the Albian, as suggested by a weak D index $(0.48-0.51)$ and strongly negative values of $\mathrm{Mn}^{*}(-0.62$ to -0.18$)$.

Above a hiatus spanning the Albian-early Oligocene time interval, slight positive values of $\mathrm{Mn}^{*}(+0.08-+0.12)$ in Oligocene to late Miocene sediments, indicate the presence of poorly oxygenated waters, while high D index values $(0.56-0.64)$ are typically those of a detrital environment (Maillot, 1982; 1986). Illite $(45 \%-75 \%)$ largely dominates the clay fraction, accompanied by smectite (traces to $45 \%$ ), chlorite (traces to $40 \%$ ), irregular mixed-layers (traces to $15 \%$ ), kaolinite $(0 \%-10 \%)$ and sporadic traces of talc (Fig. 2). Smectite is exclusive in one level only, in Core 113-693A-40R, where it probably results from the reworking of underlying smectite-rich Cretaceous sediments. Very abundant illite, and low values of the S/I index (0.03-0.65), reflect the paucity of chemical weathering onshore, as well as increased erosion of the parent-rocks on the adjacent Dronning Maud Land where schists, greywackes and intrusive rocks of Archean age outcrop (Bredell, 1982; Grikurov, 1982). The lowermost intensities of hydrolysis, i.e., cold and/or dry episodes, have been recorded near the early-late Oligocene boundary, at the Oligocene-Miocene boundary, and near the early-middle Miocene boundary. The crystallinity of illite displays important fluctuations (4.5-16): usually, weathering of illite particles (poor crystallinity) increases with temperature and/or moisture, whereas lower temperatures and/or aridity reduce the weathering (good crystallinity) and favors the development of illitic minerals (Millot, 1970; Chamley, 1974). Best illite crystallinities at Site 693 are recorded during periods of weak hydrolysis deduced from high illite contents and low values of the S/I index.

Clay mineral associations are still dominated by illite $(20 \%-$ $70 \%$ ) from the upper part of the late Miocene. Compared to the previous period its abundance decreases as well as those of chlorite $(5 \%-20 \%)$ and irregular mixed-layers $(0 \%-10 \%)$ while smectite content increases $(15 \%-65 \%)$. Kaolinite (traces to $5 \%$ ) and talc $(0 \%-5 \%)$ are also present. This is also expressed by a higher $\mathrm{S} / \mathrm{I}$ index (0.13-2.33) which is characterized by important fluctuations (Fig. 2). Relatively lower values of the D index (0.480.59 ) suggest a change in the detrital supply, into a still poorly oxygenated environment indicated by $\mathrm{Mn}^{*}$ values close to 0 . Increased smectite formation in the soils is inconsistent with the climatic evolution of the late Neogene, a period of increased glaciation and development of the West Antarctic ice-sheet (Barker, Kennett, et al., 1988). Actually, weaker hydrolysis is deduced from decreased values of the illite crystallinity (4-8.5). Thus, increased smectite contents could result from enhanced erosion of ancient smectite-rich sediments from the Antarctic margins, mainly by ice-flow and/or bottom water activity (Robert et al., 1988). Several observations support this hypothesis: (1) more abundant smectite is observed in sediments deposited under the influence of Antarctic waters; (2) dominant to exclusive smectite is present on the Southern Ocean margins, in sediments underlying Cenozoic glacial deposits (Robert and Maillot, 1983; Robert et al, 1988; this paper); (3) on the Dronning Maud Land continental margin, smectite-rich sedimentary sequences drilled at Sites 692 and 693 largely outcrop on the shelf, where they have been eroded by currents (Hinz and Krause, 1982; Barker, Kennett, et al., 1988); (4) similar mechanisms explain the presence of Mesozoic and early Cenozoic palynomorphs in modern Antarctic sediments (Kemp, 1972; Truswell and Drewry, 1984) as well as occurrences, in Arctic sediments, of clay minerals derived from the erosion of ancient shales outcropping in northern Alaska and Canada (Naidu et al., 1971; Darby, 1975). The variations of the relative abundances of smectite and illite at Site 693 probably correspond to fluctuations in climatic conditions and associated circulation.

\section{Maud Rise}

The lower part of the sedimentary sequence on Maud Rise, from the Campanian to the Eocene/Oligocene boundary, consists essentially of calcareous biogenic sediments. Terrigenous components are more abundant at the deepest Site 690 , especially in Cretaceous and Paleocene deposits. High positive val- 


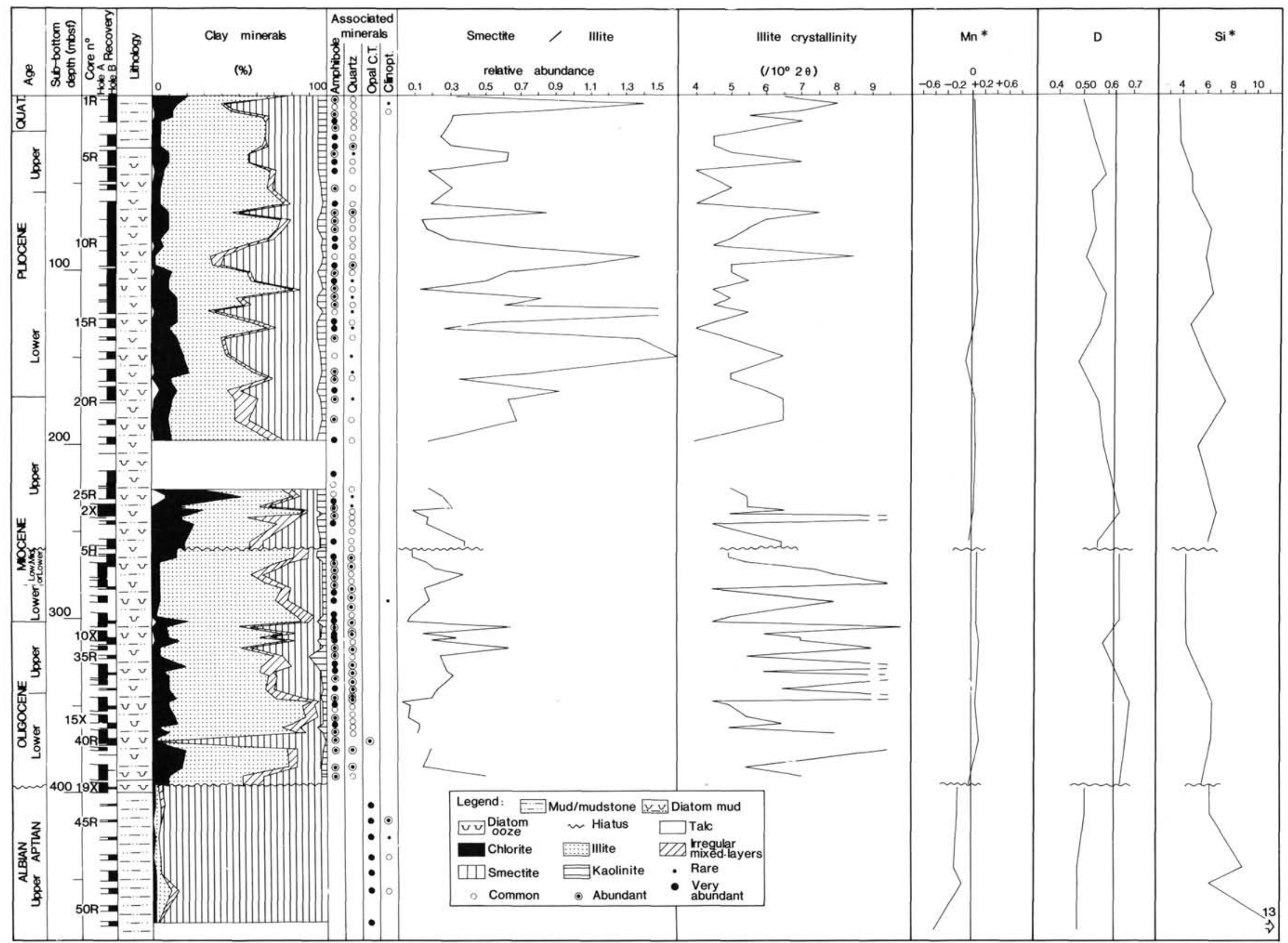

Figure 2. Clay mineral and geochemical data at Site 693, Dronning Maud Land continental margin. Smectite dominates in Cretaceous sediments. Albian to early Oligocene deposits are missing due to a hiatus. The Cenozoic sequence is largely dominated by illite. 
ues of Mn* $(+0.25-+1.15)$ suggest that Site 690 was then located in an oxidizing environment, probably a consequence of adequate deep-water circulation (Maillot, 1982; 1986). At both Sites 689 and 690 (Figs. 3, 4), smectite is dominant $(65 \%$ $100 \%)$. Illite $(0 \%-20 \%)$ is more abundant at the shallowest Site 689 . This difference is also expressed by greater values of the $\mathrm{S} /$ I index at Site 690 (5.60-70) compared to Site 689 (2-60). Kaolinite $(0 \%-20 \%)$ is present at the deepest Site 690 from the early Paleocene onward, and appears at the shallowest Site 689 during the late Eocene. There, smectite could partly result from the erosion of soils on subaerial volcanic parent-rocks, as seismic data indicate that parts of Maud Rise were probably emergent, at least during the Cretaceous (Barker, Kennett, et al., 1988). However, widespread smectite indicates that globally warm climatic conditions, associated with alternating periods of humidity and aridity, prevailed in Antarctic areas from the Cretaceous to late Eocene. Antarctic climates were then similar to those recognized on the land-masses adjacent to the different basins of the Atlantic Ocean (Chamley, 1979; Robert, 1982).

The first Cenozoic occurrence of kaolinite is in Core 113690 C-14X of early Paleocene age (Fig. 4). Kaolinite, also observed on the Falkland Plateau in Paleocene sediments (Robert and Maillot, 1983), is unknown in other South Atlantic locations of the same age (Robert, 1987), and thus probably originates from Antarctica. On Maud Rise, the mineral has not been observed at the shallowest Site 689 (Fig. 3). This suggests that a part of the detrital particles may have been carried from Antarctica northward, by deep water circulation.

Under warm climatic conditions, hydrolysis induces intensive weathering of the parent-rock, and associated removal of soluble chemical elements in well-drained areas favors the formation of kaolinite in the soils (Millot, 1970). Conditions propitious to the development of this mineral are mainly present in upstream areas of drainage basins. Better drainage conditions can be triggered by steeper continental gradients, or increased precipitation and run-off. As no tectonic activity has been reported in the Dronning Maud Land region during the early $\mathrm{Pa}-$ leogene (Grikurov, 1982), better drainage is rather associated with increased rainfall. Similar alterations of continental climate have been reported from different regions during the $\mathrm{Ce}$ nozoic and variations of the kaolinite content have been observed in coeval sediments from both hemispheres (Robert and Chamley, 1987). Thus, kaolinite formation on Antarctica during the Early Paleogene is probably favored by an increased humidity on the continent.

Maximum abundances of kaolinite $(20 \%)$ are present in Core $113-690 \mathrm{~B}-19 \mathrm{H}$. Calcareous microfaunas allow correlation of this event with Core 113-689B-23X (Thomas, this volume) where a small occurrence of kaolinite is observed. This indicates a temporary, relative homogenization of detrital supplies at both sites. In the same core, increased $\mathrm{Mn}^{*}(1.15)$ without any significant change of $\mathrm{D}$ reflects a modification of the circulation. Those events are synchronous with a virtual elimination of surface to deep isotopic gradients (Kennett and Stott, this volume) and important extinctions of deep-sea benthic foraminifers (Thomas, this volume). Increased kaolinite at Site 690 occurs to the detriment of the smectite content, and thus implies an intensified rainfall and/or a more important homogeneity of its seasonal distribution. This occurred when water temperatures on Maud Rise reached a Cenozoic maximum (Kennett and Stott, this volume). During the late Eocene, kaolinite is present from Core $113-689 \mathrm{~B}-16 \mathrm{H}$ onward, and the mineral is therefore present in both intermediate and deep waters. This event is associated with an increased illite content and lower values of the S/I index observed at both sites, indicating a reduction of chemical weathering on Antarctica which is also coeval with a cooling episode as evidenced from higher $\delta^{18} \mathrm{O}$ values beginning ca. $40 \mathrm{Ma}$. (Stott et al., this volume).

At Site 690 , both $\mathrm{Mn}^{*}$ and $\mathrm{Si}^{*}$ increase (up to +0.46 and 8.6 respectively) above a hiatus of late Eocene to early Oligocene age, indicating that the sediments were deposited in a strongly oxidizing environment which favored the development of siliceous biogenics. At both sites on Maud Rise, the clay assemblage dominated by smectite is replaced by abundant illite $(25 \%$ $60 \%$ ), associated with chlorite $(0 \%-10 \%)$, irregular mixed-layers (traces to $20 \%$ ), smectite $(15 \%-55 \%)$ and kaolinite (traces to $10 \%$ ). The $\mathrm{S} / \mathrm{I}$ index has low values, and varies from 0.7 to 1.2 at Site 689 , and from 0.20 to 0.87 at Site 690 (Figs. 3, 4). Abundant illite indicates a strong reduction of continental chemical weathering, leading to a poor soil development and increased erosion of parent-rocks. Weak hydrolysis prevents the formation of smectite, and allows only a moderate alteration of the parentrocks. This clay mineral evolution is a consequence of cold climatic conditions in East Antarctica, and is coeval with an important oxygen isotope shift (Stott et al., this volume). Absence of data near the Eocene/Oligocene boundary at Site 689 is due to the very poor terrigenous content of the sediment, which consists almost exclusively of calcareous biogenics, suggesting intensive productivity and/or winnowing by this time on Maud Rise.

At both sites, a hiatus spans the upper part of the early Miocene. Above the hiatus, the smectite content as well as the S/I index are higher (Figs. 3, 4). Evolution of the clay mineral association on Maud Rise is now inconsistent with climatic conditions leading to the glaciation of Antarctica: ice-sheets developed especially during the Miocene (Kennett and Von der Borch, 1985), and chlorite and illite are the major components of the soils in modern ice-free areas (Campbell and Claridge, 1982; Ugolini and Jackson, 1982). This observation is similar to that mentioned regarding Neogene sediments from Site 693 on the Dronning Maud Land continental margin. Thus, more abundant smectite on Maud Rise indicates increased erosion of ancient smectite-rich sediments outcropping on the Antarctic margins. Initiation of this process on Maud Rise just post-dates the hiatus, and is probably a consequence of a change in oceanic circulation.

\section{Weddell Basin}

The oldest sediments recovered from the Weddell Basin are of middle Miocene age (Fig. 5). In this sedimentary column, D index values fluctuate from 0.52 to 0.80 and $\mathrm{Mn}^{*}$ values from -0.32 to +0.48 (but generally slightly positive) indicating that the environment is typically detrital and poorly oxidized. From Cores $113-694 \mathrm{C}-23 \mathrm{X}$ to $-20 \mathrm{X}$, both chlorite $(25 \%-45 \%)$ and illite $(40 \%-45 \%)$ dominate the clay fraction, and are associated with smectite $(5 \%-20 \%)$ and kaolinite $(0 \%-10 \%)$. The S/I index has low values $(0.06-0.38)$ and illite crystallinity displays important fluctuations (2.5-8). This clay assemblage indicates weak weathering processes in the source area. Contemporary clay mineral associations on Dronning Maud Land continental margin and Maud Rise do not show such significant percentages of chlorite. Thus, the clay fraction in the Weddell Basin is, at least in part, of different origin. This is corroborated by the composition of the lithic elements of the turbidites and glacial materials recovered at Site 694 , which suggest that the terrigenous deposits there originate from West rather than from East Antarctica (Barker, Kennett, et al., 1988).

From Core 113-694C-18X onward, the percentages of illite $(25 \%-55 \%)$ and chlorite $(15 \%-35 \%)$ display important fluctuations relative to smectite $(10 \%-55 \%)$. The $\mathrm{S} / \mathrm{I}$ index $(0.10$ $1.20)$ and illite crystallinity $(2.5-8)$ are also characterized by important variations. The clay mineralogical change is coeval with 


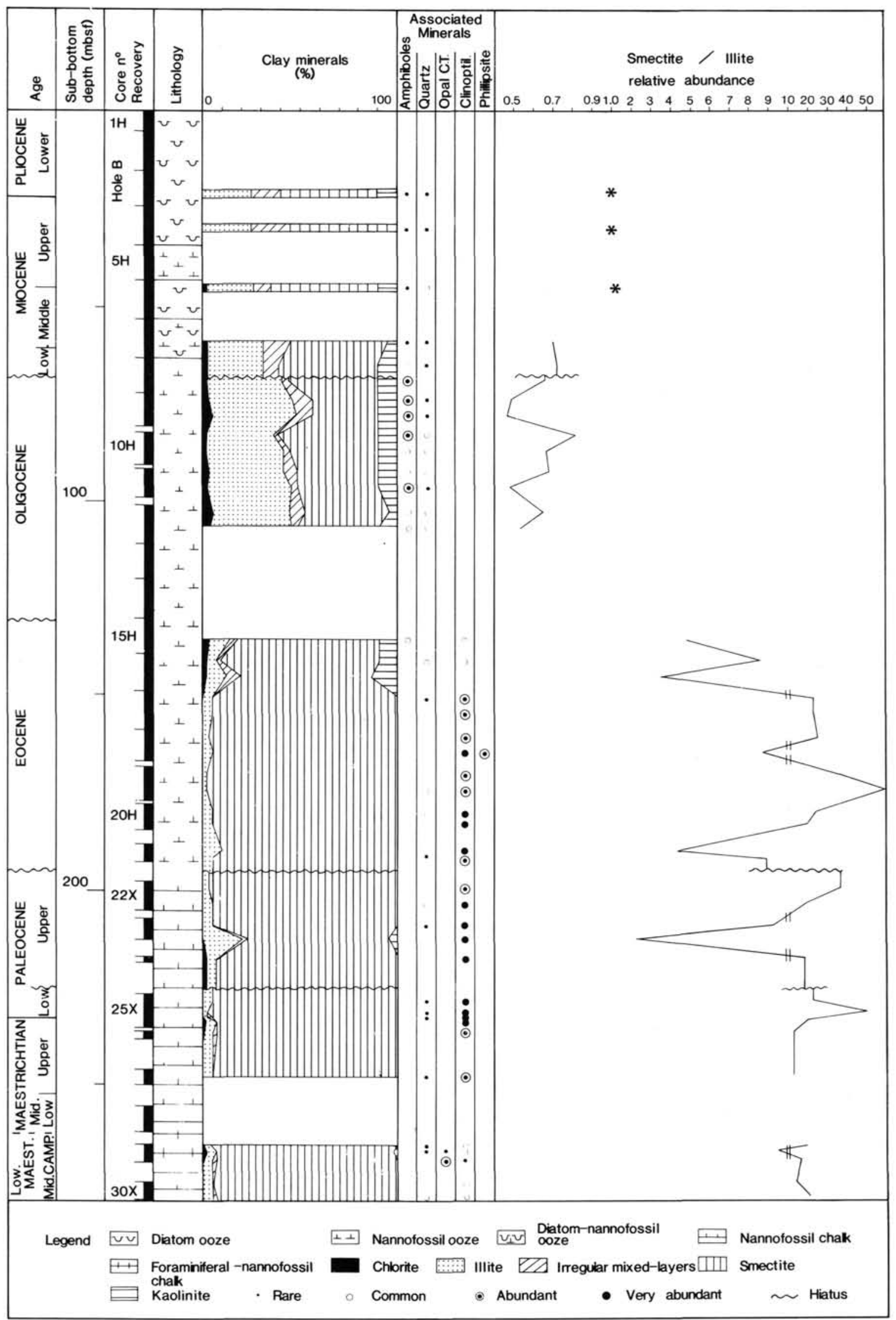

Figure 3. Clay mineral data at Site 689, Maud Rise. Clay content in lower Oligocene and middle Miocene to lower Pliocene sediments was insufficient to allow precise estimation of the clay species. Smectite dominates in Upper Cretaceous to upper Eocene deposits. Higher illite contents, and lower S/I values are present from Oligocene sediments upsection. 


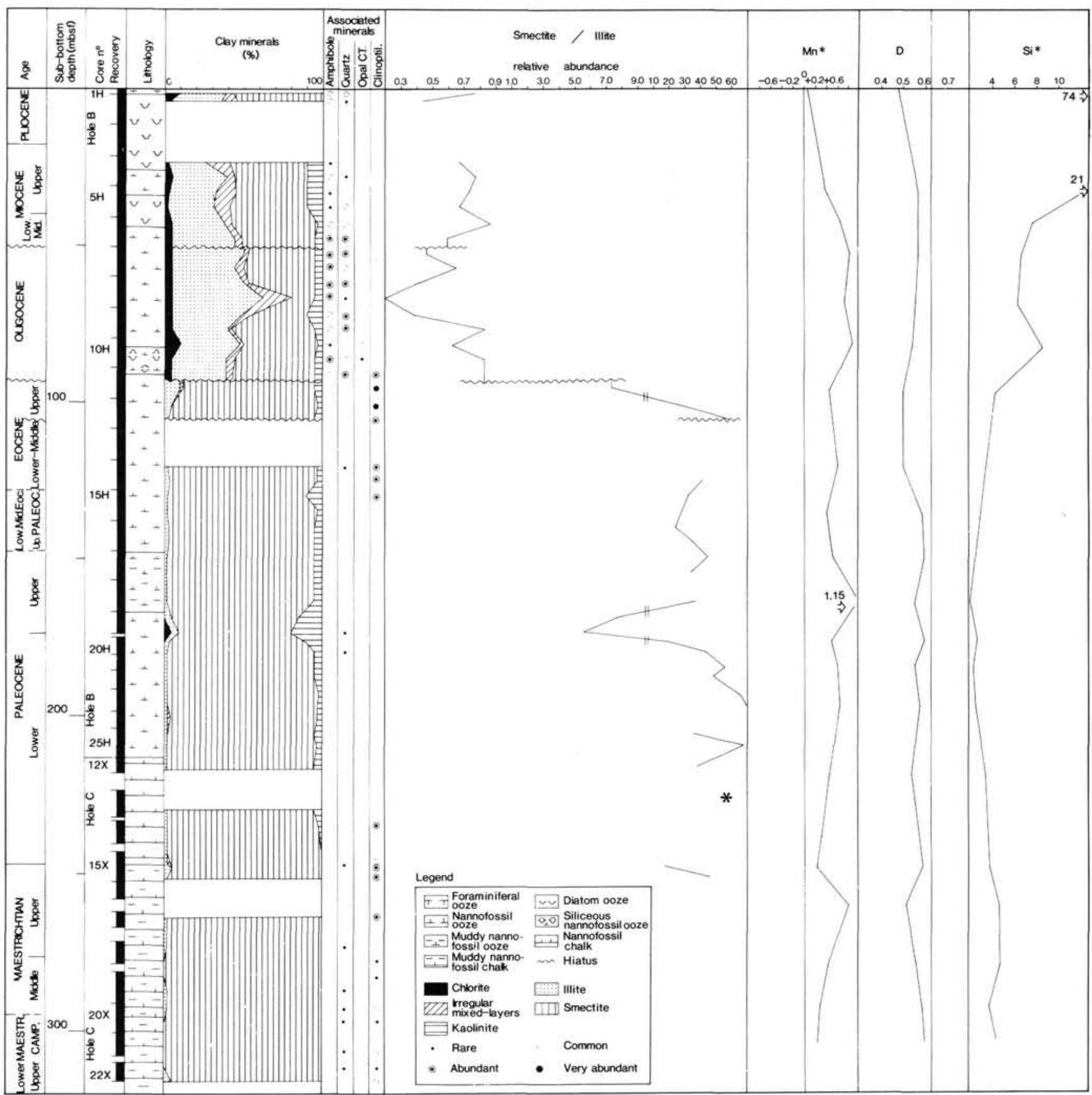

Figure 4. Clay mineral and geochemical data at Site 690, Maud Rise. Clay content in middle Eocene and upper Miocene to Pliocene sediments was insufficient to allow precise estimation of the clay species. Smectite dominates in Upper Cretaceous to upper Eocene deposits. Kaolinite is more abundant in lower Paleocene to middle Eocene sediments there than at Site 689. Higher illite contents, and lower S/I values are present from the Eocene/Oligocene boundary upsection.

the variability of $\mathrm{Mn}^{*}, \mathrm{D}$, and $\mathrm{Si}^{*}$ values (Fig. 5), suggesting that significant oxidizing conditions and more important detrital supplies, probably linked to enhanced oceanic circulation, were temporarily present in the Weddell Basin from the upper part of the middle Miocene. Abundant smectite, associated with poorly crystallized, weathered illite, suggests increased erosion on continental margins, whereas abundant chlorite associated with well-crystallized illite indicates periods propitious to the development of poorly weathered soils. Importance of the fluctuations denotes that climatic conditions were then very unsta- ble, as also evidenced from sedimentological observations (Barker, Kennett, et al., 1988).

From the upper part of the late Miocene (Core 113-694B$24 \mathrm{X})$, the smectite content $(25 \%-70 \%)$ increases at the expense of chlorite (traces to $20 \%$ ) while illite $(25 \%-50 \%)$ remains approximately constant (Fig. 5). Lower supply of chlorite depends on weaker weathering conditions in West Antarctica while increasing smectite contents suggest intensified erosion of the Antarctic margins. The highest percentages of smectite and maximum values of the $\mathrm{S} / \mathrm{I}$ index (up to 2.12 ) are recorded during 


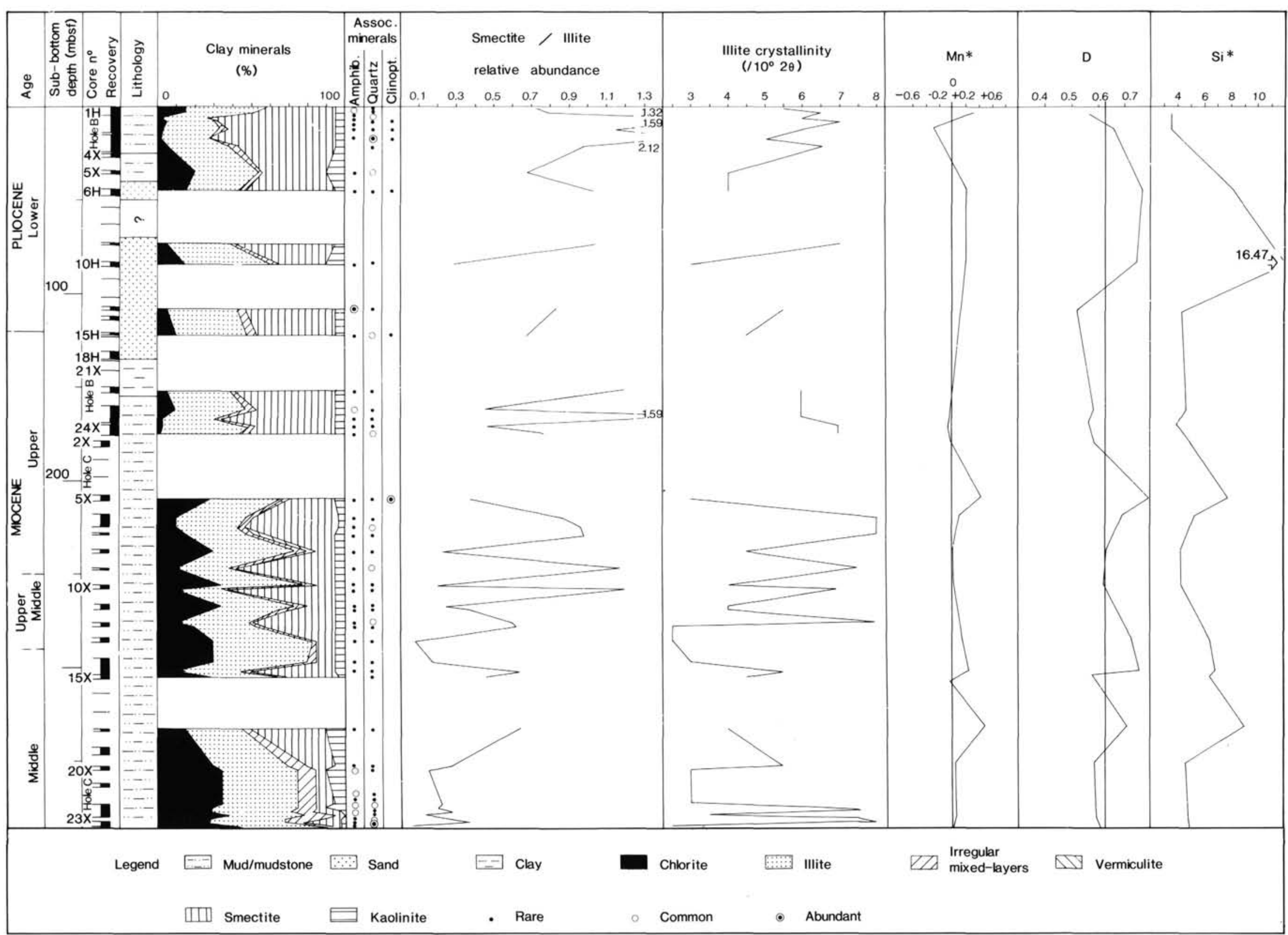

Figure 5. Clay mineral and geochemical data at Site 694, Weddell Basin. Chlorite and illite are dominant in middle Miocene deposits. Note increasing abundances of smectite upsection. 
the early Pliocene (Cores 113-694B-3H and $-2 \mathrm{H}$ ), probably in relation to enhanced current activity. This episode is probably coeval (lower Upsilon radiolarian zone) with a similar event recorded in Cores 113-697B-26X to -19X in Jane Basin (Fig. 8). Different data have been obtained off East Antarctica at Site 693 (Fig. 2), where contemporary clay mineral associations reflect a decrease of erosional processes.

\section{South Orkney Microcontinent}

From the middle Eocene to the middle Miocene, alternating claystones and mudstones were deposited in a shallow-water environment on the South Orkney microcontinent, changing to diatomites and diatom oozes in the upper part of the section (Barker, Kennett, et al., 1988). From the lower part of Site 696 up to Core 113-696B-50R of middle Miocene age, strongly negative values of $\mathrm{Mn}^{*}(-0.48$ to -0.16$)$ indicate the persistence of a poorly oxidized environment, while typical values of the D index (0.58-0.66) suggest that the sediment is mainly detrital. Smectite prevails in all sediments $(65 \%-100 \%)$, and is accompanied by illite (traces to $25 \%$ ), chlorite (traces to $10 \%$ ), irregular mixed-layers and kaolinite (sporadic traces); the $\mathrm{S} / \mathrm{I}$ index ranges from 1.79 to 16 (Fig. 6). Smectite consists mainly of fleecy particles with blurred outlines, which are commonly found in soils. Its dominance indicates that the detrital supply originates mainly from continental areas characterized by warm climate, with alternating wet and arid periods. These climatic conditions were then still present in most parts of East and West Antarctica. Ubiquity of "glauconitic" illite in Core 113-696B-57R, and good preservation of the transparent crystals (Pl. 4) suggest that they formed in close proximity to the site, in a confined shallow-water environment enriched in $\mathrm{Fe}$ and $\mathrm{K}$, which also probably favored the formation of green grains (glaucony), abundant in this core.

Beginning in the early Oligocene, clay mineral associations on the South Orkney microcontinent differ from those deposited on the Dronning Maud Land continental margin and Maud Rise, where chlorite and illite prevail. On the South Orkney microcontinent, smectite remains dominant, and becomes increasingly dominant as sediments get younger, indicating that the clay minerals still originate mainly from continental areas characterized by a globally warm climate, as was the case on the Falkland Plateau during the same time interval (Robert and Maillot, 1983). However, pollen data indicate a temperature drop (Mohr, this volume, chapter 36) in the upper part of the sedimentary sequence (Cores 113-696B-54R to $-51 \mathrm{R}$ ). These data suggest that at Site 696 , clay particles originate mainly from warmer regions probably located in South America, and transported by southward currents to the South Orkney microcontinent. Importance of these currents, and associated detrital supply, probably increased while cooling progressed on Antarctica: effectively, the deficit of heat in the polar areas tends to be compensated by transports of energy from intertropical regions toward the high latitudes, and the western boundary current system of the South Atlantic plays a major role in this process (Wells, 1986).

In Cores 113-696B-49R and -48R, the $\mathrm{Mn}^{*}$ index progresses to values close to 0 and $\mathrm{Si}^{*}$ increases (up to 27), indicating more oxidizing conditions and more important planktonic productivity, probable consequences of slightly increasing oceanic circulation. A dramatic drop of smectite content $(35 \%-60 \%)$ is associated with significant increases of chlorite $(10 \%)$, irregular mixed-layers $(5 \%-15 \%)$ and especially illite $(20 \%-40 \%)$ abundances, and is also evidenced from an important decrease $(0.90$ 2.0) of the S/I index (Fig. 6). This clay association resembles that of middle Miocene age observed at other Leg 113 sites (Figs. 2-5), and now originates from continental areas where weak hydrolysis prevents the development of the soils and favors physical weathering and erosional processes. During the same time interval, in the Falkland Plateau area at DSDP Sites 329 and 513 , clay assemblages are still characterized by dominant smectite (Robert and Maillot, 1983). The clay mineralogical change at Site 696 occurred within the Nitzschia grossepunctata diatom zone, ca. $15 \mathrm{Ma}$ (Barker, Kennett, et al, 1988), coeval with a major ice-volume increase in East Antarctica (Kennett and Von der Borch, 1985).

These data are consistent with previous models of plate tectonic and climatic evolution. Following the beginning of seafloor spreading between South America and the Antarctic Peninsula during the early Miocene (Barker and Burrell, 1977), the Drake Passage and Scotia Sea formed progressively. It is possible that a change in plate geometry and spreading rate ca. 16 Ma (Barker et al., 1984) played a role in the development of the passageway. Consequently, initiation of the Antarctic Circumpolar Current through Drake Passage isolated the terrigenous detrital supplies of both South America and West Antarctica, and increased oxidizing conditions in the South Orkney area. At the same time, glaciation progressed in Antarctica.

Data from the middle and late Miocene at Site 696 are sparse, due to poor recovery. However, a clay fraction dominated by illite $(10 \%-35 \%)$ and chlorite $(20 \%-45 \%)$, accompanied by smectite $(10 \%-45 \%)$, irregular mixed-layers $(0 \%-15 \%)$ and kaolinite (traces to $10 \%$ ) is present throughout this time-interval (Fig. 6). Values of the S/I index decrease progressively $(0.20-1.43)$. This clay mineral association indicates weak hydrolysis in the source area, during a period characterized by increased cooling and glaciation of Antarctica (Kennett and Von der Borch, 1985).

In the upper part of the late Miocene and in the lower part of the early Pliocene (Figs. 6-8), smectite is more abundant at the deeper Sites $695(35 \%-75 \%)$ and $697(45 \%-75 \%)$ than at the shallower Site $696(25 \%-60 \%)$. Mean values of the S/I index are 0.5 at Site $696,0.8$ at Site 695 and 1.20 at Site 697. This distribution could result from differential settling of detrital particles. However, its importance decreases with distance offshore while its complexity increases (Gibbs, 1977). Experimental computerization of settling processes suggests that mainly particles greater than $4 \mu \mathrm{m}$ in size are affected, for water depths above $1000 \mathrm{~m}$ (Brun-Cottan, 1976). Thus, differential settling probably played a minor role in the smectite enrichment of the deeper parts of Jane Basin. The eastern flank of the South Orkney Microcontinent and Jane Basin being on the path of Antarctic Bottom Water flowing out of the Weddell Sea (Pudsey et al, 1988 ), sedimentation at deeper depths is probably more influenced by distal detrital supply from the West Antarctic margin.

During early Pliocene times, increased smectite content and $\mathrm{S} / \mathrm{I}$ index, associated with decreased chlorite and $\mathrm{C} / \mathrm{I}$ index occur at both Sites 695 and 697 (Figs. 7, 8). At shallower depths, increase of smectite begins in Core 113-695A-32X (Fig. 7), just near the lower-upper Tau radiolarian zone boundary, and near the Distephanus pseudofibula-Distephanus boliviensis silicoflagellate zone boundary, ca. 4.2-4.4 Ma. At the deepest site, increased smectite contents occur in Core 113-697B-26X (Fig. 8), located in upper Tau or lower Upsilon radiolarian zones, well above the Distephanus pseudofibula-Distephanus boliviensis boundary, and is consequently younger than $4.2 \mathrm{Ma}$ at this site. Increase of smectite began later at the deepest Site 697. Thus, this mineralogic change is probably not directly dependent on a local climatic event, which would have influenced both sites at the same time. Clay associations are probably altered by an increased influence of Antarctic waters in the Jane Basin area, and this influence was conspicuous earlier at intermediate water depths. Farther East, in the Atlantic sector of the Southern Ocean, increased circulation of Antarctic waters has been depicted from the distribution of early Pliocene disconformities: 


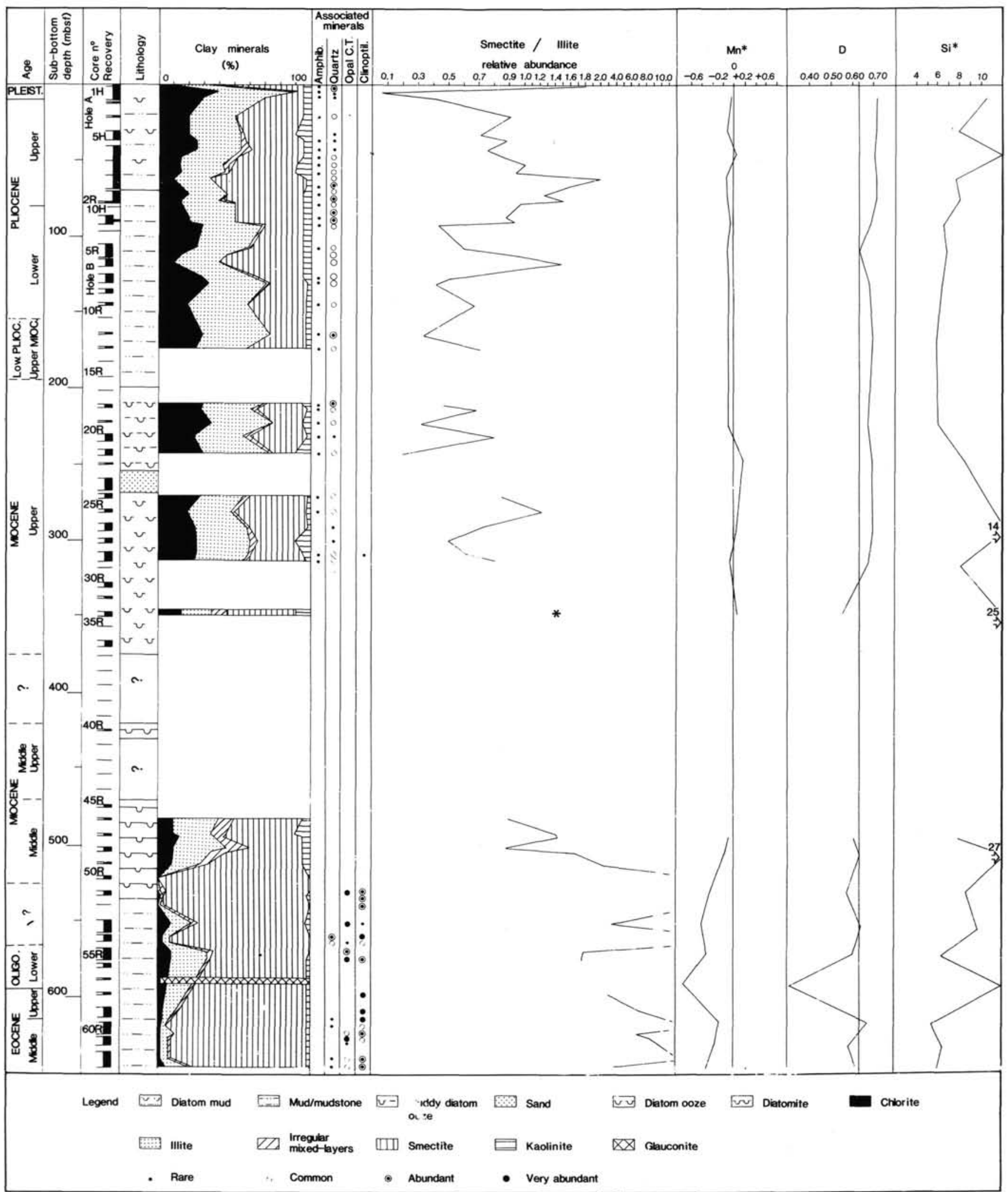

Figure 6. Clay mineral and geochemical data at Site 696, South Orkney microcontinent. Smectite dominates in middle Eocene to middle Miocene sediments. Abundant chlorite and illite are present in middle Miocene sediments and upsection. Note general similarity of the clay associations and time-shift in the records between East (Sites 689, 690 and 693) and West (Site 696) Antarctica. 


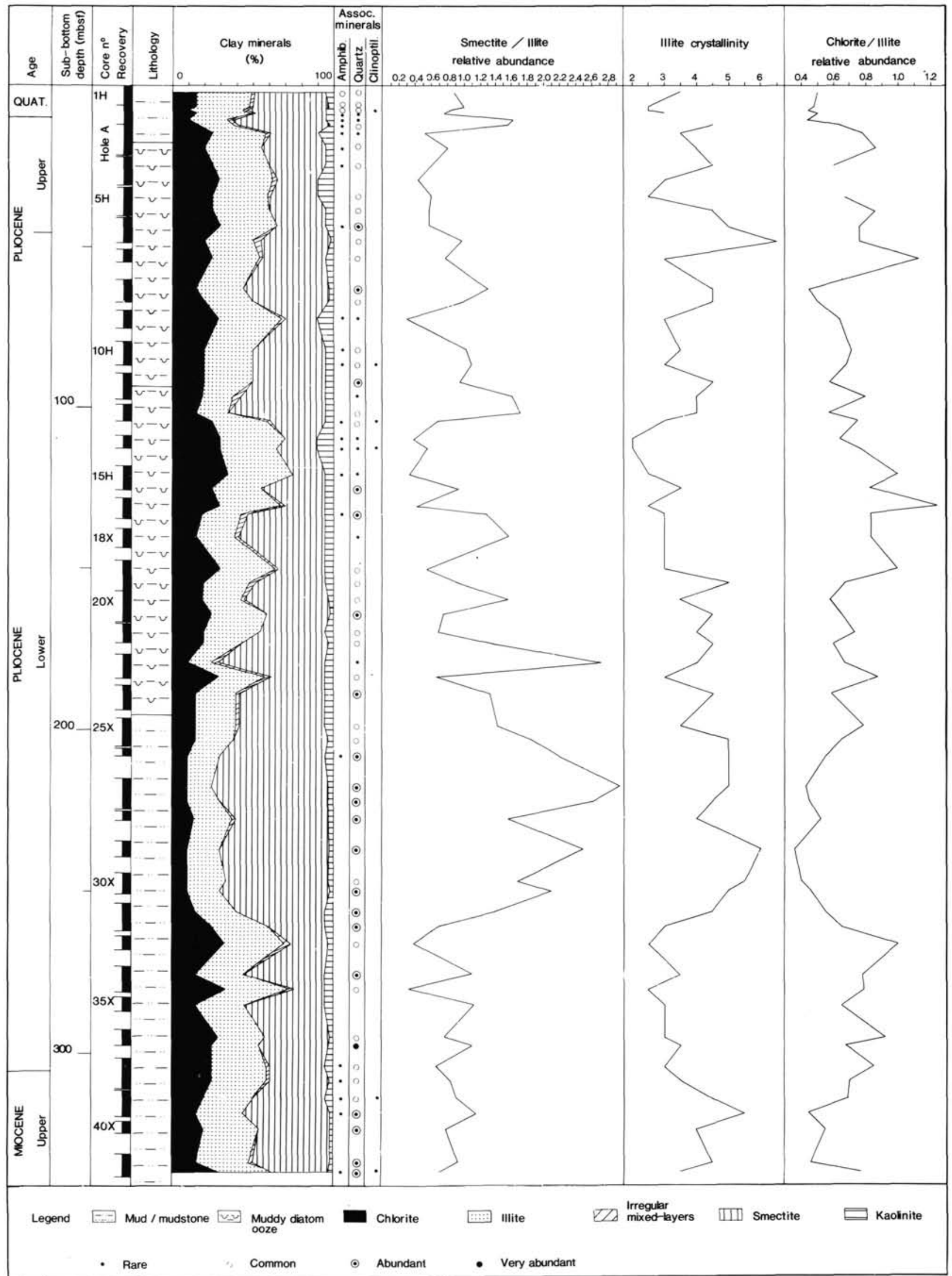

Figure 7. Clay mineral data at Site 695 in Jane Basin. Note the variations of the relative abundances of chlorite, illite, and smectite. 


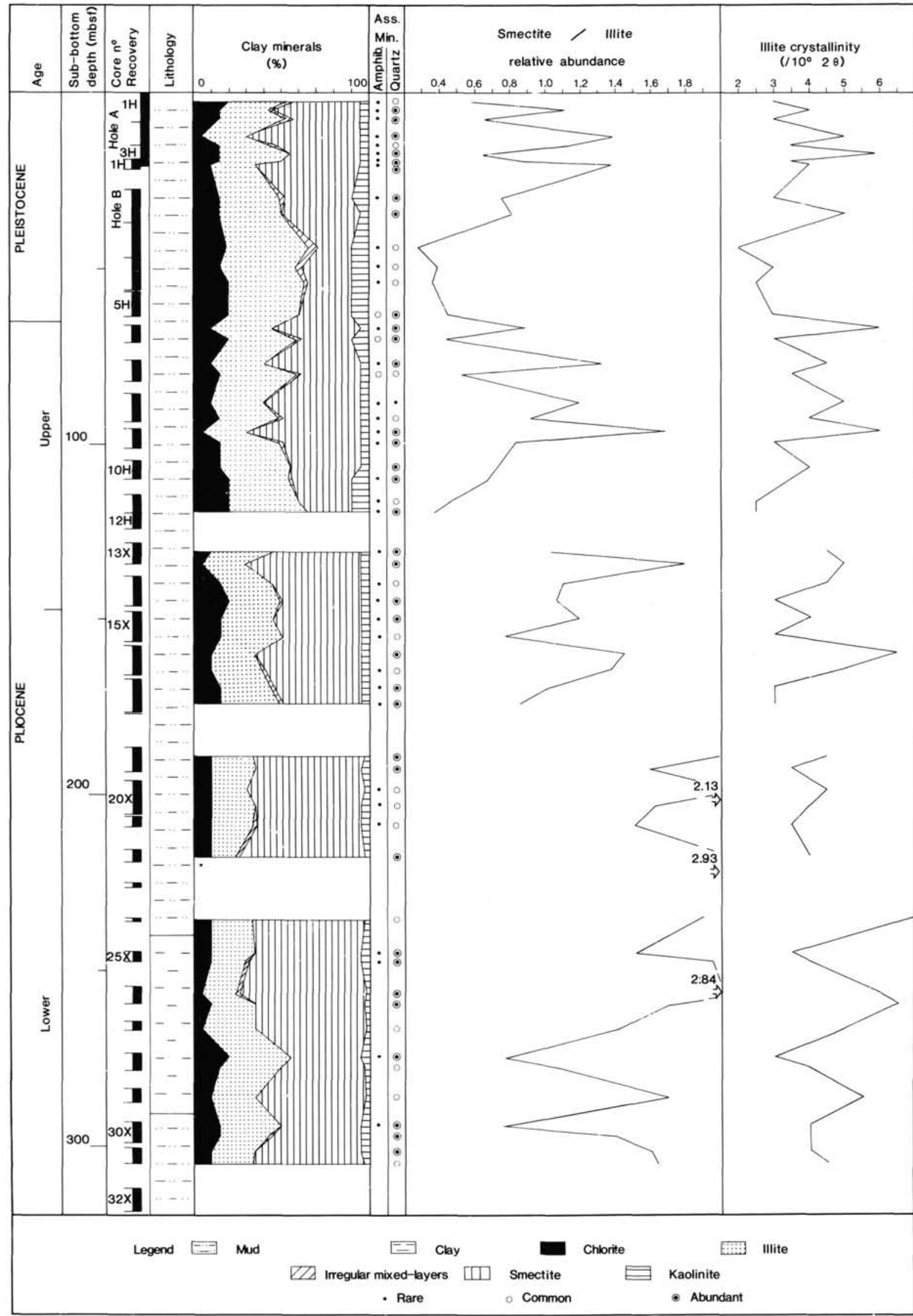

Figure 8. Clay mineral data at Site 697 in Jane Basin. Note the variations of the relative abundances of smectite and illite, and the higher smectite contents here than at the shallower Sites 695 and 696 in the same region. 
here also, enhanced influence of Antarctic waters is observed earlier at shallower water depths (Ledbetter and Ciesielski, 1986). Increased smectite contents extend up to Core 113-695A-21X at the shallower site (Fig. 7), i.e., in the upper part of the lower Upsilon radiolarian zone (ca. 3.2-3.6 Ma), and up to Core 113697B-18X at the deeper site (Fig. 8), i.e., in the middle part of the middle Upsilon radiolarian zone (ca. 3.0 Ma). As a consequence, the increased influence of circulation lasted longer in deeper water.

Above this, increased abundance of chlorite and higher $\mathrm{C} / \mathrm{I}$ values from Cores 113-695B-20X to $-13 \mathrm{H}$ (Fig. 7) probably results from an increased proximal detrital supply, originating from the South Orkney microcontinent and Antarctic Peninsula, where climatic conditions permitted only weak pedogenesis and weathering over deglaciated areas.

A further increase of smectite content and of the $\mathrm{S} / \mathrm{I}$ index is evidenced from Cores 113-697B-10H to $-5 \mathrm{H}$ at the deeper site (Fig. 8), and in Cores 113-695A-3 H and -2 $\mathrm{H}$ in intermediate waters (Fig. 7). At both sites, increased smectite contents span a period extending from the upper part of the upper Upsilon to the Chi or Phi radiolarian zones, and from the upper boundary of the Nitzschia interfrigidaria to the upper part of the Coscinodiscus kolbei-Rhizosolenia barboi diatom zones, i.e., from 2.82.5 to $2.0 \mathrm{Ma}$ approximately. Increased smectite indicates an enhanced influence of Antarctic waters in the Jane Basin, and is probably coeval with an intensified hiatus frequency evidenced in the Southern Ocean basins during the early Matuyama (Ledbetter and Ciesielski, 1986).

The Pleistocene sequence is well represented at Site 697 only. From Cores 113-697B-5H to -3H, in the lower part of the Pleistocene, higher chlorite contents and a very low S/I index (Fig. 8) indicate that erosion of sediments decreased while detrital supply from poorly developed soils increased. It suggests a weaker influence of bottom water circulation. The mineralogical change correlates with a decrease in Antarctic Bottom Water production previously observed in the subantarctic area of the South Atlantic (Ledbetter and Ciesielski, 1982). A similar event has been recorded at DSDP Site 513 in the South Atlantic (Robert and Maillot, 1983).

Smectite content and the S/I index increase from Core 113697B-2H to the seafloor (Fig. 8). This change precedes the Matuyama-Brunhes boundary, and probably began around 850,000 yr B.P. It indicates an enhanced influence of Antarctic waters. It is probably coeval with a global augmentation, and the beginning of sharp variations of the $\delta^{18} \mathrm{O}$, evidenced especially in a Pacific core (Shackleton and Opdyke, 1976) and at DSDP Site 502 (Prell, 1982). This period is known to mark an expansion of the Northern Hemisphere ice-sheets, and the beginning of major glacial/interglacial episodes (Kennett and Von der Borch, 1985).

\section{CONCLUSIONS}

In the Weddell Sea, temporal variations in the clay mineral associations and inorganic geochemical data have been mainly controlled by continental climate and oceanic circulation since Cretaceous times. These variations express the modifications of the environment, as cooling and glaciation progressed on Antarctica (Table 2).

1. Dominant smectite suggests the presence of warm climatic conditions with alternating wet and arid seasons during the Cretaceous. This climate persisted until the Eocene/Oligocene boundary in East Antarctica, and lasted into the Oligocene in West Antarctica.

2. Beginning with the early Paleocene, occurrences of kaolinite on Maud Rise probably result from increased humidity on Antarctica. The presence of this mineral at the deepest Site 690 only suggests that the detrital supply is partly carried by deep-water circulation. Temporary increases of kaolinite content in deep water, associated with higher $\mathrm{Mn}^{*}$ and coeval with minor occurrences of kaolinite at intermediate water depth, indicate increased humidity on the continent and relative homogenization of the detrital supplies within the water column.

Table 2. Chronology and interpretation of the major clay mineralogical events, correlated with the paleoceanographic evolution in Southern high latitudes. Major events are from Frakes (1979), Kennett (1982), Barker et al. (1984), Kennett and Von der Borch (1985), Ledbetter and Ciesielski (1986), and Stott et al. (this volume).

\begin{tabular}{|c|c|c|c|}
\hline Age & Signals & Interpretations & Major events \\
\hline $\begin{array}{l}\text { early Pliocene } \\
4.2-4.4 \mathrm{Ma}\end{array}$ & Fluctuations of smectite content at all sites. & $\begin{array}{l}\text { Fluctuations of Antarctic water } \\
\text { activity. }\end{array}$ & $\begin{array}{l}\text { Increased Antarctic bottom water and } \\
\text { circumpolar deep water activity. }\end{array}$ \\
\hline $\begin{array}{l}\text { late Miocene } \\
5.5 \mathrm{Ma}\end{array}$ & Increased smectite at Site 693 & $\begin{array}{l}\text { Increased erosion by ice and/or } \\
\text { currents. }\end{array}$ & $\begin{array}{l}\text { Increased ice volume on West } \\
\text { Antarctica. }\end{array}$ \\
\hline $\begin{array}{l}\text { middle Miocene } \\
15 \mathrm{Ma}\end{array}$ & $\begin{array}{l}\text { Dominant illite (and chlorite) at Sites } 694 \\
\text { and } 696 \text {. Increased Mn* and D at Site } \\
\text { 696. Increased smectite on Maud Rise. }\end{array}$ & $\begin{array}{l}\text { Widening of Drake Passage and } \\
\text { Scotia Sea isolated West } \\
\text { Antarctica. Strong cooling, } \\
\text { increased erosion by ice and } \\
\text { Antarctic waters. }\end{array}$ & $\begin{array}{l}\text { Major increase of East Antarctica ice } \\
\text { sheet. Change in plate geometry } \\
\text { in the Scotia Sea. }\end{array}$ \\
\hline Oligocene to middle Miocene & Dominant smectite at Site 696. & $\begin{array}{l}\text { Important detrital supply from } \\
\text { warm areas, by southward } \\
\text { surface currents off West } \\
\text { Antarctica. }\end{array}$ & \\
\hline $\begin{array}{l}\text { Eocene-Oligocene boundary } \\
\quad 37 \mathrm{Ma}\end{array}$ & $\begin{array}{l}\text { Dominant illite on Maud Rise and Dronning } \\
\text { Maud Land margin. Higher values of } \\
\text { Mn* at Site } 690 \text {. }\end{array}$ & $\begin{array}{l}\text { Strong cooling in East Antarctica, } \\
\text { more oxygenated waters. }\end{array}$ & $\begin{array}{l}\text { Cooling, cryospheric development of } \\
\text { East Antarctica. Production of } \\
\text { cold, dense Antarctic waters. }\end{array}$ \\
\hline $\begin{array}{l}\text { late Eocene } \\
40 \mathrm{Ma}\end{array}$ & $\begin{array}{l}\text { Increased illite contents on Maud Rise; } \\
\text { occurrences of kaolinite at Site } 689 .\end{array}$ & $\begin{array}{l}\text { Middle cooling in East Antarctica; } \\
\text { increased detrital supply by } \\
\text { intermediate waters. }\end{array}$ & Discrete cooling in Antarctic areas. \\
\hline $\begin{array}{l}\text { Paleocene-Eocene boundary } \\
57.5 \mathrm{Ma}\end{array}$ & $\begin{array}{l}\text { Maximum kaolinite content at Site } 690 \text {; } \\
\text { minor occurrence at Site } 689 \text {; high } \mathrm{Mn}^{*} \\
\text { values. }\end{array}$ & $\begin{array}{l}\text { Maximum humidity in East } \\
\text { Antarctica; homogenization of } \\
\text { the detrital supplies within the } \\
\text { water column. }\end{array}$ & $\begin{array}{l}\text { Cenozoic maximum of water } \\
\text { temperatures. }\end{array}$ \\
\hline $\begin{array}{l}\text { early Paleocene } \\
\quad 66 \mathrm{Ma}\end{array}$ & First occurrence of kaolinite at Site 690. & $\begin{array}{l}\text { Increased humidity in East } \\
\text { Antarctica; detrital supply by } \\
\text { deep waters. }\end{array}$ & \\
\hline $\begin{array}{l}\text { Late Cretaceous to } \\
\text { Eocene-Oligocene boundary }\end{array}$ & Dominant smectite & $\begin{array}{l}\text { Warm climate; alternating wet and } \\
\text { arid seasons. }\end{array}$ & $\begin{array}{l}\text { Tropical to subtropical climate up to } \\
70^{\circ} \mathrm{S} \text {; temperate beyond. }\end{array}$ \\
\hline
\end{tabular}


3. Following a mild reduction of hydrolysis during the late Eocene, clay associations off East Antarctica are dominated by chlorite, illite, and irregular mixed-layers above the Eocene/Oligocene boundary. This assemblage indicates a strong decrease of chemical weathering, associated with cold climatic conditions on the continent and more oxidizing conditions in the ocean. A warmer climate persisted until the middle Miocene in West Antarctica, warmed by southward flowing surface currents. Then, widening and deepening of Drake Passage and the Scotia Sea permitted a full development of the Antarctic Circumpolar Current and completed the thermal isolation of both East and West Antarctica; since then, similar clay associations prevailed in the detrital supplies off East and West Antarctica.

4. Beginning during the early middle Miocene on Maud Rise, during the late Miocene on Dronning Maud Land continental margin and during the early Pliocene off West Antarctica, increases of the smectite content under glacial climatic conditions imply erosion of ancient sediments on the Antarctic margins by enhanced circulation and/or ice-flow. Fluctuating abundances of the mineral evidence periods of increased deep water activity during the early Pliocene (4.2-4.4 to $3.0 \mathrm{Ma}$ ), the late Pliocene $(2.8-2.5$ to $2.0 \mathrm{Ma}$ ) and the late Pleistocene (after 0.85 Ma).

\section{ACKNOWLEDGMENTS}

Financial support for this study was provided by the Centre National de la Recherche Scientifique (ASP-ODP). We should like to express our thanks to S. Bieda, M. Decobert, B. Domeyer, P. Recourt, J. P. Ripert, L. Seigle, and the UA-CNRS "Etudes Géologiques Ouest-Africaines" for technical assistance. We are grateful to H. Chamley, J. F. Deconinck, J. P. Kennett, and C.P.G. Pereira for stimulating discussions, aid, and constructive comments, as well as to A. Gunatilaka and two reviewers who improved the original manuscript.

\section{REFERENCES}

Barker, P. F., and Burrell, J., 1977. The opening of Drake Passage. Mar. Geol., 25:15-34.

Barker, P. F., Barber, P. L., and King, E. C., 1984. An early Miocene ridge crest-trench collision on the Scotia Ridge near $36^{\circ}$ West. Tectonophysics., 102:315-332.

Barker, P. F., Kennett, J. P., et al, 1988. Proc. ODP, Init. Repts., 113: College Station, TX (Ocean Drilling Program).

Berggren, W. A., Kent, D. V., Flynn, J. J., and Van Couvering, J. A., 1985. Cenozoic Geochronology. Geol. Soc. Am. Bull., 96:1407-1418.

Beutelspacher, H., and Van der Marel, H. W., 1968. Atlas of electron microscopy of clay minerals and their admixtures: Amsterdam (Elsevier).

Biscaye, P. E., 1965. Mineralogy and sedimentation of recent deep-sea clay in the Atlantic Ocean and adjacent seas and oceans. Geol. Soc. Am. Bull., 76:803-832.

Boström, K., 1970. Submarine volcanism as a source of iron. Earth Planet. Sci. Lett., 9:348-384.

Boström, K., Joensuu, O., Valdes, S., Charm, W., and Glaccum, R., 1976. Geochemistry and origin of East Pacific sediments samples during DSDP Leg 34. In Yeats, R. S., Hart, S. R. et al, Init. Repts. $D S D P$, 34: Washington (U.S. Govt. Printing Office), 559-574.

Bredell, J. H., 1982. The Precambrian sedimentary-volcanic sequence and associated intrusive rocks of the Ahlmannryggen, Western Dronning Maud Land: a new interpretation. In Craddock, C. (Ed.), Antarctic Geoscience, I.U.G.S. Series B, 4:591-597.

Brun-Cottan, J. C., 1976. Stokes settling and dissolution rate model for marine particles as a function of size distribution. J. Geophys. Res., 81:1601-1605.

Campbell, I. B., and Claridge, G.G.C., 1982. The influence of moisture on the development of soils of the cold deserts of Antarctica. Geoderma, 28:221-238.

Chamley, H., 1974. Place des argiles marines parmi divers indicateurs paléoclimatiques. In Les méthodes quantitatives d'étude des variations du climat au cours du Pléistocène. Colloques Internationaux du CNRS, 219:Paris (CNRS), 25-37.
1979. North Atlantic clay sedimentation and paleoenvironment since the Late Jurassic. In Talwani, M., Hay, W. W., and Ryan, W.B.F. (Eds.), Deep Drilling Results in the Atlantic Ocean: Continental Margins and Paleoenvironments: Washington (Am. Geophys. Union), 342-360.

1980. Clay sedimentation and paleoenvironment in the Shikoku Basin since the middle Miocene (DSDP Leg 58, North Philippine Sea). In Klein, G. de V., Kobayashi, K. et al., Init. Repts. DSDP, 58: Washington (U.S. Govt. Printing Office), 669-681. , 1989. Clay Sedimentology. New York (Springer-Verlag).

Chamley, H., and Bonnot-Courtois, C., 1981. Argiles authigènes et terrigènes de l'Atlantique et du Pacifique NW (Legs 11 et 58 DSDP): apport des terres rares. Oceanol. Acta, 4:229-238.

Chamley, H., Maillot, H., Duée, G., and Robert, C., 1984. Paleoenvironmental history of the Walvis Ridge at the Cretaceous-Tertiary transition, from mineralogical and geochemical investigations. In Moore, T. C., Rabinowitz, P. D. et al, Init. Repts DSDP, 74: Washington (U.S. Govt. Printing Office), 685-695.

Darby, D. A., 1975. Kaolinite and other clay minerals in Arctic Ocean sediments. J. Sediment. Petrol., 45:272-279.

Deconinck, J. F., Strasser, A., and Debrabant, P., 1988. Formation of illitic minerals at surface temperatures in Purbeckian sediments (lower Berriasian, Swiss and French Jura). Clay Miner., 23:91-103.

Diester-Haass, L., and Chamley, H., 1978. Neogene paleoenvironment off Northwest Africa based on sediments from DSDP Leg 14. J. Sediment. Petrol., 48:879-896.

Dingle, R. V., Siesser, W. G., and Newton, A. R., 1983. Mesozoic and Tertiary Geology of Southern Africa: Rotterdam (A. A. Balkema).

Elderfield, H., 1977. The form of manganese and iron in marine sediments. In Glasby, G. P. (Ed.), Marine manganese deposits: Amsterdam (Elsevier).

Frakes, L. A., 1979. Climates throughout geologic time: Amsterdam (Elsevier).

Gac, J. Y., 1979. Géochimie du bassin du lac Tchad. Bilan de l'altération, de l'érosion et de la sédimentation [D. Sci. Dissert.]. Université Louis Pasteur, Strasbourg, France.

Gibbs, R. J., 1977. Clay mineral segregation in the marine environment. J. Sediment. Petrol., 47:237-243.

Hinz, K., and Krause, W., 1982. The continental margin of Queen Maud Land, Antarctica: seismic sequences, structural elements and geological development. Geol. Jahrb. Reihe E, 23:17-41.

Holtzapffel, T., 1985. Les minéraux argileux. Préparation. Analyse diffractométrique et détermination. Soc. Géol. Nord, Publ. 12.

Holtzapffel, T., and Chamley, H., 1986. Les smectites lattées du domaine atlantique depuis le Jurassique supérieur: gisement et signification. Clay Miner., 21:133-148.

Kemp, E. M., 1972. Recycled palynomorphs in continental shelf sediments from Antarctica. Antarctic J., 7:5.

Kennett, J. P., 1982. Marine Geology: Englewood-Cliffs, N.Y. (Prentice-Hall).

Kennett, J. P., and Von der Borch, C., 1985. Southwest Pacific Cenozoic paleoceanography. In Kennett, J. P., Von der Borch, C. et al, Init. Repts. DSDP, 90: Washington (U.S. Govt. Printing Office), 1493-1517.

Krishnaswami, S., 1976. Authigenic transition elements in Pacific pelagic clays. Geochim. Cosmochim. Acta, 40:425-434.

Ledbetter, M. T., and Ciesielski, P. F., 1982. Bottom current erosion in the South Atlantic sector of the Southern Ocean. Mar. Geol., 46: 329-341.

1986. Post-Miocene disconformities and paleoceanography in the Atlantic sector of the Southern Ocean. Palaeogeogr. Palaeoclimatol. Palaeoecol., 52:185-214.

Maillot, H., 1982. Les paléoenvironnements de l'Atlantique Sud: apport de la géochimie sédimentaire [D. Sci. Dissert.]. Université des Sciences et Techniques de Lille, France.

1986. Détermination des traits principaux des grands courants océaniques actuels, superposés dans l'Atlantique sud-occidental, par l'étude géochimique des sédiments. C.R. Acad. Sci. Paris, 303 , Série 2:1123-1128.

Martin, A. K., Goodlad, S. W., Hartnady, C.J.H., and Du Plessis, A., 1982. Cretaceous paleopositions of the Falkland Plateau relative to Southern Africa, using Mesozoic seafloor spreading anomalies. Geophys. J.R. Astron. Soc., 71:571-579.

Millot, G., 1970. Geology of clays. New-York (Springer-Verlag). 
Naidu, A. S., Burrell, D. C., and Hood, D. W., 1971. Clay mineral composition and geologic significance of some Beaufort Sea sediments. J. Sediment. Petrol., 41:691-694.

Paquet, H., 1970. Evolution géochimique des minéraux argileux dans les altérations et les sols des climats méditerraneens et tropicaux a saisons contrastées. Sci. Géol. Strasbourg, Mém. 30.

Prell, W. L., 1982. Oxygen and carbon isotope stratigraphy for the Quaternary of Hole 502B: evidence for two modes of isotopic variability. In Prell, W. L., Gardner, J. V. et al, Init. Repts. DSDP, 68: Washington (U.S. Govt. Printing Office), 455-466.

Pudsey, C. J., Barker, P. F., and Hamilton, N., 1988. Weddell Sea abyssal sediments: a record of Antarctic Bottom Water flow. Mar. Geol., 81:289-314.

Robert, C., 1982. Modalité de la sédimentation argileuse en relation avec l'histoire géologique de l'Atlantique Sud [D. Sci. Dissert.], Université d'Aix-Marseille 2, France.

1987. Clay mineral associations and structural evolution of the South Atlantic: Jurassic to Eocene. Palaeogeogr. Palaeoclimatol. Palaeoecol., 58:87-108.

Robert, C., and Maillot, H., 1983. Paleoenvironmental significance of clay mineralogical and geochemical data, Southwest Atlantic, Deep Sea Drilling Project Legs 36 and 71. In Ludwig, W. J., Krasheninnikov, V. et al, Init. Repts. DSDP, 71: Washington (U.S. Govt. Printing Office), 317-343.

Robert, C., Stein, R., and Acquaviva, M., 1985. Cenozoic evolution and significance of clay associations in the New Zealand region of the South Pacific, DSDP Leg 90. In Kennett, J. P., Von der Borch, C. et al, Init. Repts. DSDP, 90: Washington (U.S. Govt. Printing Office), $1225-1238$.

Robert, C., and Chamley, H., 1987. Cenozoic evolution of continental humidity and paleoenvironment, deduced from the kaolinite content of oceanic sediments. Palaeogeogr. Palaeoclimatol. Palaeoecol., 60: 171-187.

Robert, C., Caulet, J. P., and Maillot, H., 1988. Evolution climatique et hydrologique en mer de Ross (Site DSDP 274) au Néogène, d'après les associations de radiolaires, la minéralogie des argiles et la géochimie minérale. C.R. Acad. Sci. Paris, 306, Série 2:437-442.

Shackleton, N. J., and Opdyke, N. P., 1976. Oxygen isotope and paleomagnetic stratigraphy of Pacific Core V 28-239, late Pliocene to latest Pleistocene. Geol. Soc. Am. Mem., 145:449-464.

Stein, R., and Robert, C., 1985. Siliciclastic sediments at Sites 588, 590 and 591: Neogene and Paleogene evolution in the Southwest Pacific and Australian climate. In Kennett, J. P., Von der Borch, C. et al Init. Repts. DSDP, 90: Washington (U.S. Govt. Printing Office), 1437-1455.

Truswell, E. M., and Drewry, D. J., 1984. Distribution and provenance of recycled palynomorphs in surficial sediments of the Ross Sea, Antarctica. Mar. Geol., 59:187-214.

Turekian, K. K., 1965. Some aspects of the geochemistry of marine sediments. In Riley, J. P., and Skirrow, G. (Eds.), Chemical Oceanography: London (Academic Press), 2:81-126.

Ugolini, F. C., and Jackson, M. L., 1982. Weathering and mineral synthesis in Antarctic soils. In Craddock, C. (Ed.), Antarctic Geoscience, I.U.G.S. Series B, 4:1101-1108.

Wells, N., 1986. The Atmosphere and Ocean: a physical introduction. London (Taylor and Francis).

Date of initial receipt: 24 October 1988

Date of acceptance: 15 September 1989

Ms 113B-151 
PALEOENVIRONMENTS DEDUCED FROM CLAY MINERAL ASSOCIATIONS AND GEOCHEMICAL DATA
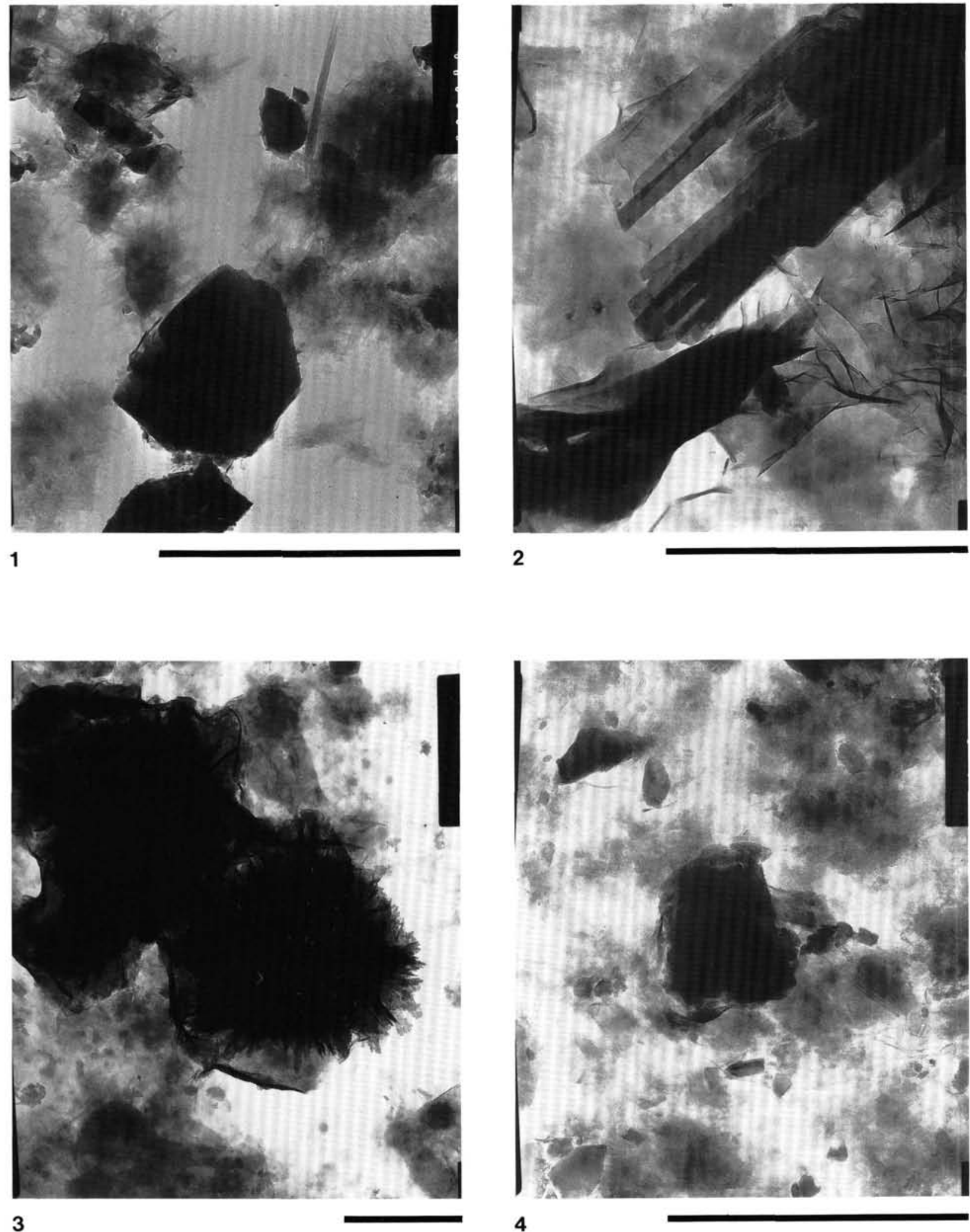

Plate 1. Electromicrographs (Scale bar $=1 \mu \mathrm{m}$ ). 1. Sample 113-689B-8H-2, $52 \mathrm{~cm}$, lower Miocene; very thin laths associated in geometrical figures, sometimes growing at the periphery of particles, in a clay fraction containing $55 \%$ smectite, $30 \%$ illite, $10 \%$ kaolinite, and $5 \%$ irregular mixed-layers. 2. Sample 113-689B-25X-5, $103 \mathrm{~cm}$, Cretaceous/Tertiary boundary; thick lathed particles and thin veils, associated with fleecy particles in the background, in a clay fraction containing $100 \%$ smectite. 3. Sample 113-689B-29X, CC, $22 \mathrm{~cm}$, lower Maestrichtian to middle Campanian; globular packs of thin laths, associated with fleecy particles, in a clay fraction containing $95 \%$ smectite and $5 \%$ illite. 4. Sample $113-690 \mathrm{~B}-5 \mathrm{H}-5,54 \mathrm{~cm}$, lower to middle Miocene; dominant fleecy particles in a clay fraction containing 50\% smectite, $30 \%$ illite, $10 \%$ kaolinite, and $10 \%$ irregular mixedlayers. 


\section{ROBERT, H. MAILLOT}
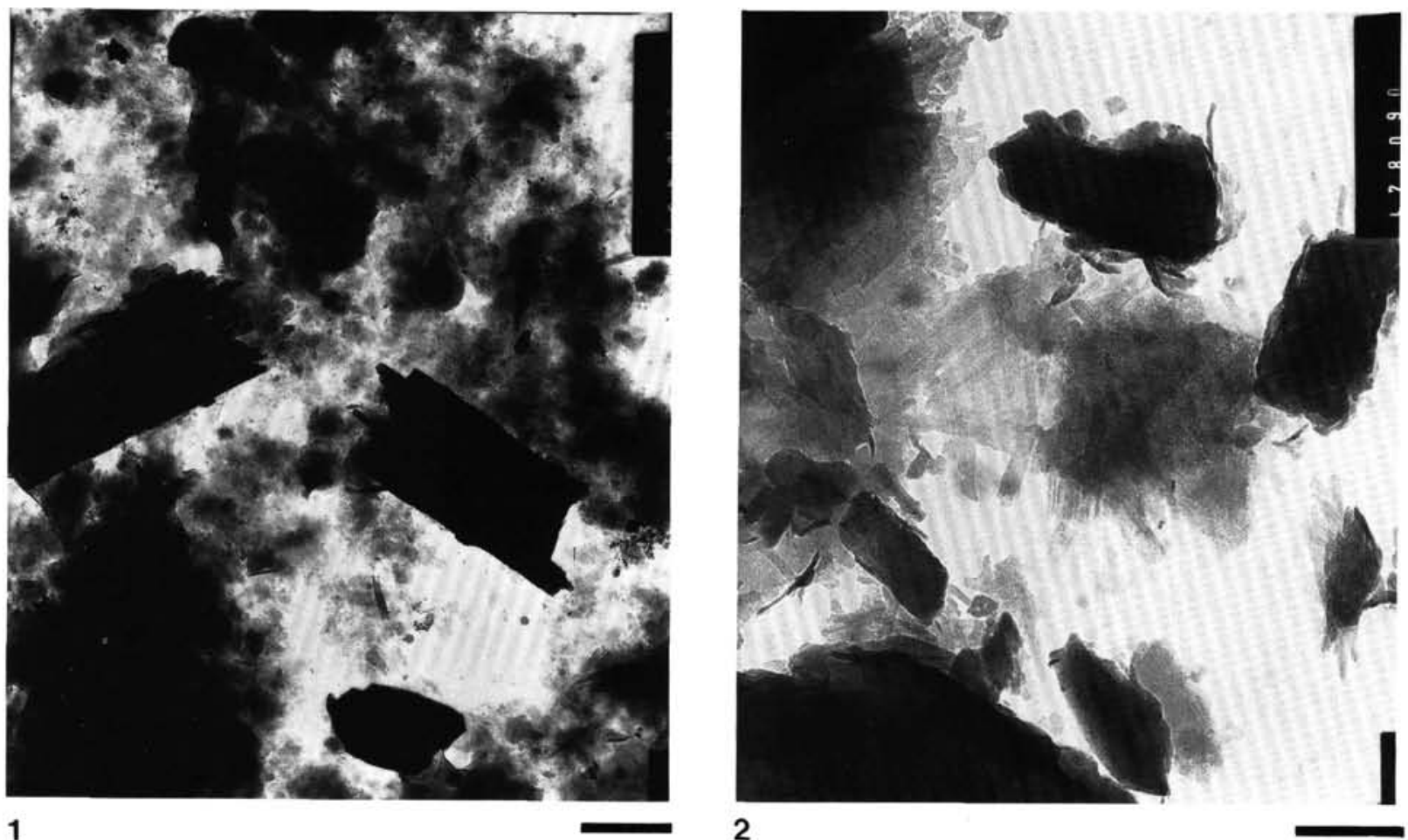

1

2
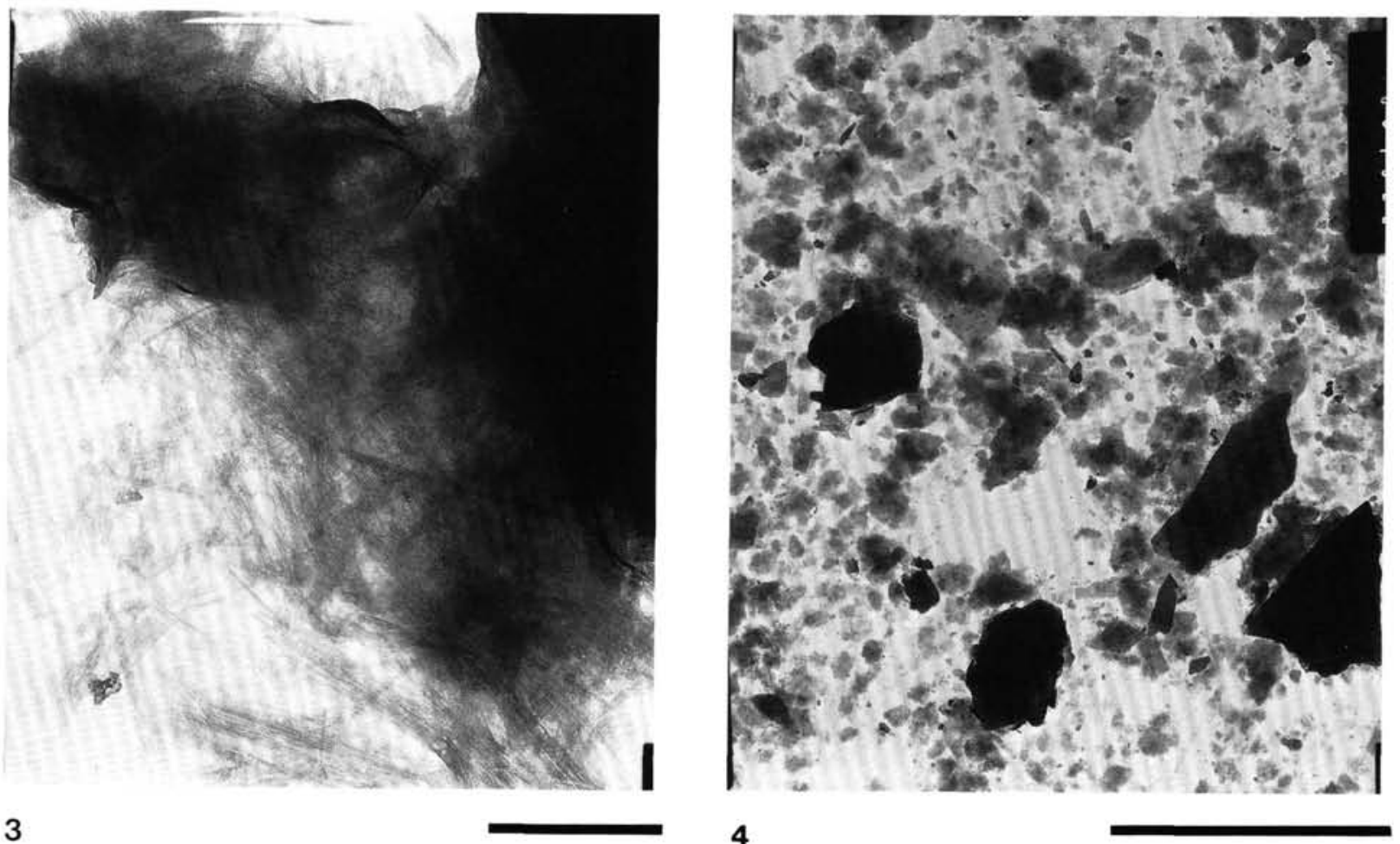

3

\section{4}

Plate 2. Electromicrographs (Scale bar $=1 \mu \mathrm{m}$ ). 1. Sample 113-690C-15X-4, $75 \mathrm{~cm}$, Cretaceous/Tertiary boundary; very thick laths associated with fleecy particles, in a clay fraction containing $95 \%$ smectite and $5 \%$ illite. 2. Sample 113-693A-39R-2, $50 \mathrm{~cm}$, lower Oligocene; thin laths associated in geometrical figures, short, probably broken, with traces of erosion and dissolution, in a clay fraction containing $75 \%$ illite, $10 \% \mathrm{smectite,} 10 \%$ irregular mixed-layers, and 5\% kaolinite. 3. Sample 113-693B-19X-4, $108 \mathrm{~cm}$, Albian to upper Aptian; long thin laths sometimes associated in geometrical figures, in a clay fraction containing $100 \%$ smectite. 4. Sample 113-694A-1H-5, $105 \mathrm{~cm}$, lower Pliocene; dominant fleecy particles, associated with big particles with sharp outlines, in a clay fraction containing $75 \%$ smectite, $25 \%$ illite, and $5 \%$ kaolinite. 

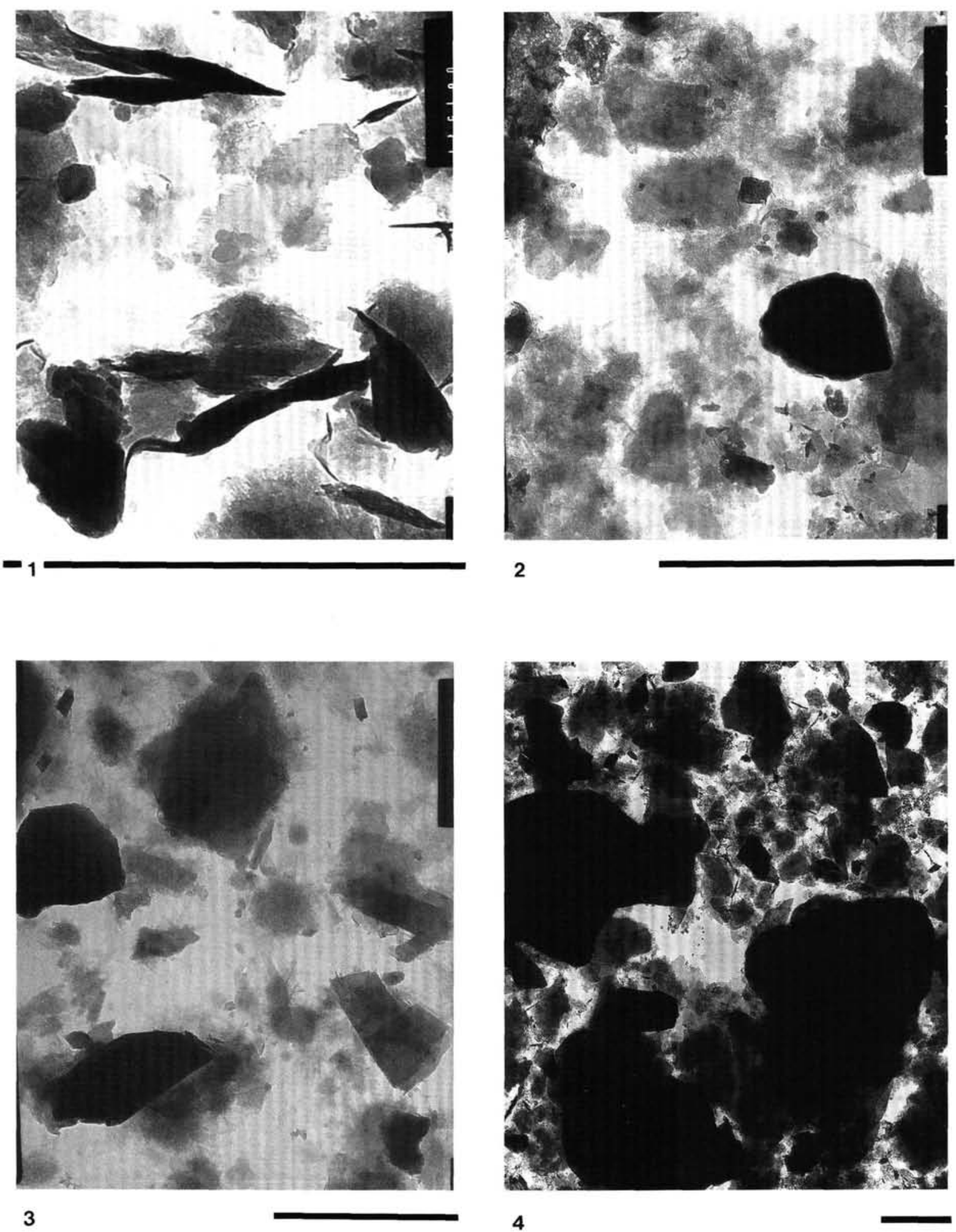

3

Plate 3. Electromicrographs (Scale bar $=1 \mu \mathrm{m}$ ). 1. Sample 113-694C-8X-1, $105 \mathrm{~cm}$, upper Miocene; very small particles surrounded by short thin laths, broken and eroded, in a clay fraction containing $45 \%$ illite, $30 \%$ chlorite, $10 \%$ smectite, $5 \%$ irregular mixed-layers, kaolinite, and vermiculite. 2. Sample 113-694C-23X-2, $107 \mathrm{~cm}$, middle Miocene; fleecy particles, and very thin laths generally associated in geometrical figures with $60^{\circ}$ angles, in a clay fraction containing $45 \%$ chlorite, $40 \%$ illite, $10 \%$ irregular mixed-layers, and 5\% smectite. 3. Sample 113-695A-27X-2, 105 cm, lower Pliocene; very thin laths associated in geometrical figures, or growing at the periphery of big particles, sometimes broken, in a clay fraction containing 70\% smectite, $20 \%$ illite, and 10\% chlorite. 4. Sample 113-696B-6R-2, $105 \mathrm{~cm}$, lower Pliocene; big particles with sharp outlines and abundant fleecy particles, in a clay fraction containing $60 \%$ smectite, $30 \%$ illite, $10 \%$ chlorite, and $5 \%$ kaolinite. 


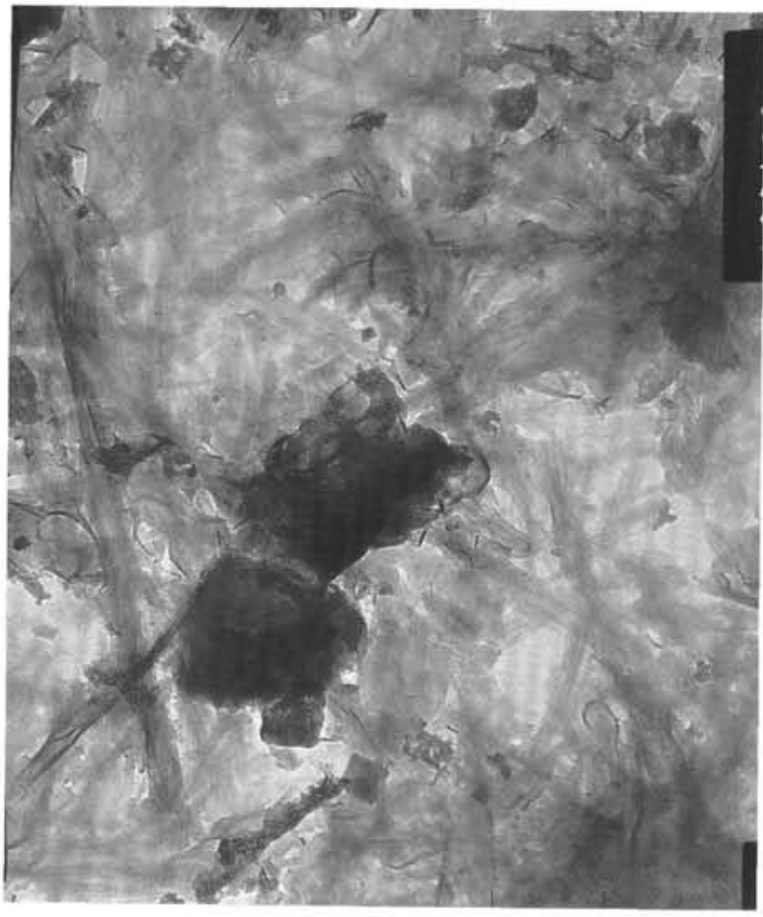

1

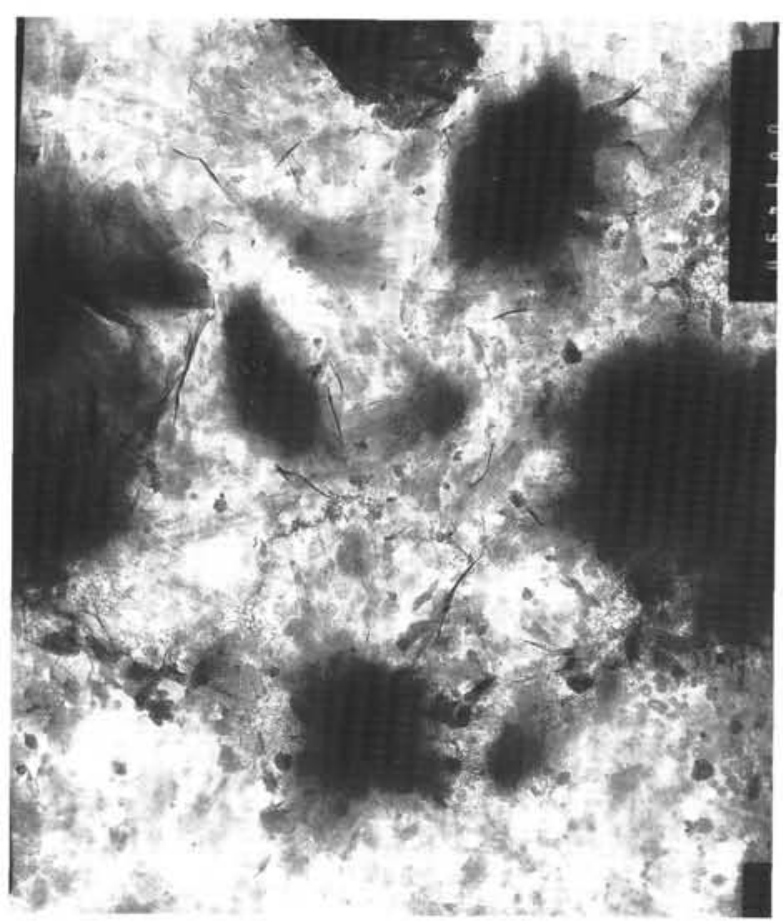

2

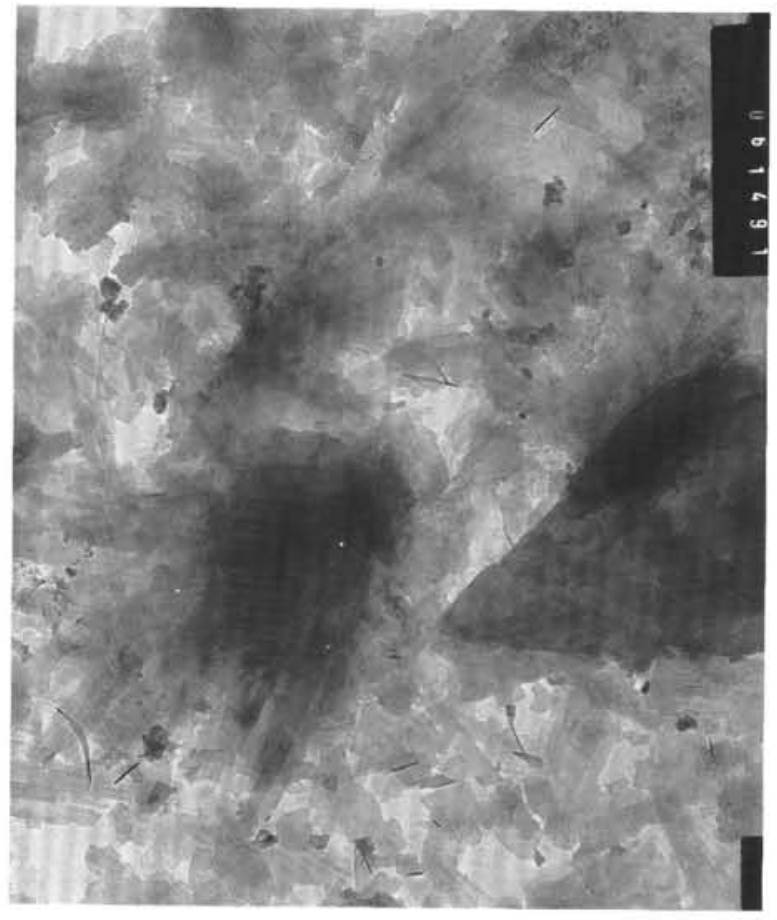

3

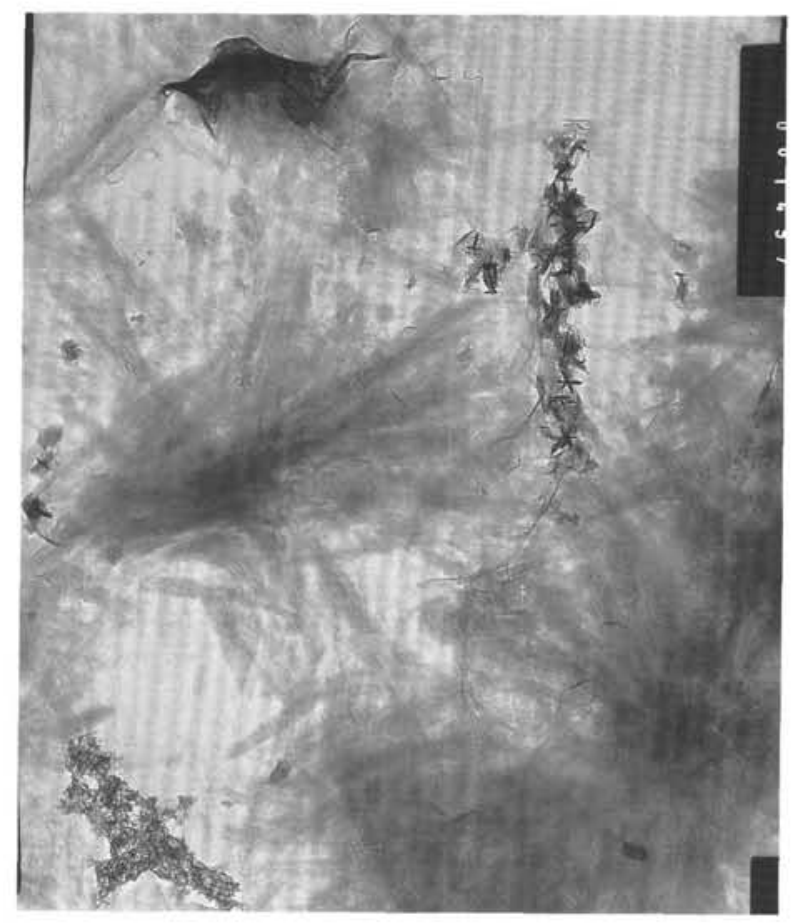

4

Plate 4. Electromicrographs (Scale bar $=1 \mu \mathrm{m}$ ). 1. Sample 113-696B-50R-1, $109 \mathrm{~cm}$, middle Miocene; very thin laths in a clay fraction containing $100 \%$ smectite. 2-3. Sample 1123-696B-57R-1, $102 \mathrm{~cm}$, lower Oligocene; laths and well-shaped crystals with sharp outlines, in a clay fraction containing $100 \%$ illite ("glauconite"). 4. Sample 113-696B-62R-4, $98 \mathrm{~cm}$, middle Eocene; very thin laths, sometimes associated in geometrical figures with $60^{\circ}$ angles, in a clay fraction containing $80 \%$ smectite, $15 \%$ illite, and $5 \%$ chlorite. 